\title{
Sandhyopaasan:The Hindu Ritual as a Foundation of Vedic Education
}

\author{
Rajendra Raj Timilsina
}

\begin{abstract}
Yoga, meditation and Hasta Mudra Chikitsa (medication through the exercise or gesture of hands) known as spiritual activities in the past have been emerged as bases to maintain one's health, peace and tranquility. Some people follow yoga, some focus on meditation and others apply "Hasta Chikitsa" or "Mudra". They are separate traditional exercises. They require to spend 10 to 30 minutes once or twice a day for their optional exercise/s. It is proved that such practice has productive effect in different health treatments. This paper has applied the methods of observation, interview and literature review as qualitative paradigm in exploring their original roots of Vedic Sandhyopaasan. Twice born castes (Brahman, Chhetri and Baishya) of Nepali Hindu society has been found practicing all components of the exercises as a unified ritual of Sandhyopaasan. Upanayan (Bratabandha) ritual teaches Sandhyopaasan procedures for self control and self healing of the performers. Brahman is not eligible as Brahman without doing the ritual daily. However, this study has found that some Dalits have also been practicing Sandhyopaasan daily and feeling relaxed. Findings of this study show that Sandhyopaasan is a compact package of yoga, meditations and Hasta Chikitsa. Students and gurus of Vedas have been regularly following the compact package for inner peace and self control. Root of yoga, meditation and "Mudra" is Sandhyopaasan and this is the base of Hindu education system. The paper analyzes the ritual through Hindu educational perspective.
\end{abstract}

Keywords: Sandhyopaasan, ritual, peace of mind, health, Nepali Hinduism 


\section{4| Rajendra Raj Timilsina}

\section{Introduction}

Generally, Brahman, Chhetri and Baishya perform daily ritual of Sandhyopaasan under Hindu society. Sandhyopaasan is basic essential code of conduct for faithful Brahman. Otherwise, he is not eligible Brahman as priest for religious rites as well as study of Vedas and Puranas, according to Vedic tradition (Acharya Kaundinnyanah, 2004). Taitteriya Aaranyak of Yajurveda, Ishavashya Upanishad of Shukla Yajurveda and Chhandogya Upanishad have explained the procedure of worshiping of the Sun and meditation. Vedic religious scriptures state that one who does not perform Sandyopaasan is considered ever impure.

The ritual is a compact package of yoga, meditation, pray and chanting mantras. The package is performed as major tool of self control and peace of a human being. Such practices have been found helpful for health recovery among different groups though they may not be exact Sandhyopaasan ritual. "A recent study shows that cognitive theory combined with daily practice of meditation, yoga and other healthenhancing behaviors can be as long-term antidepressant medication alone in preventing relapse in patients who have had several bents of major depression"(Stubenrauch, 2011). Hindu schooling adopts such practices as a major step of socialization. According to Sitholy, Agrawal and Vrat (2013), education is "swaddhyay" which means studies, learning Vedas, doing "Sandhyopaasana" (pray by reciting and meditating on "Gaayatree" mantra at times when day and night meet) and doing "agnihotra" (rituals in which fire is lighted). As stated by Devi, et al. (2011), there are various procedures involved in dincharya (ideal daily life-style) directly affects the mind of individual. These procedures increase the satwa (purity) level in mind and thus maintain mental health of individual. Yoga and meditation have different names geographically and religiously in recent decades. Some have named as Praanayaam and others as Yogaasan for yoga. Actually, it was propounded by ancient sage Patanjali. The yoga-system of Patanjali or the ancient Hindu doctrine of concentration of mind, embracing the mnemonic rules, called Yogasutras of Patajali, and the comment, called Yoga-bhashya (https:// archive.org/details/yogasystemofpata00wooduoft). The philosophy of Patanjali is not mere exercise but mega theory of "do's and don'ts" for peaceful human life. Patanjali's yoga has been embraced with meditational part as well. Sannyasi Yogasindhu (1997) sees yoga psychology has been developed as a re-emerging field: 


\section{5| Rajendra Raj Timilsina}

yoga psychology has important applications in managing psychological, psychosomatic and social problems as well as in promoting and transcending the self. Meditation practices for health is a part of Yoga (Büssing Arndt, et al., 2012) may be practiced at least in part as a self-care behavioral treatment, provides a life-long behavioral skill, enhances self-efficacy and self-confidence and is often associated with additional positive side effects. Some other scholars and yogis have differentiated meditation part from Yoga.

Yoga and meditation have psychotherapy-related construct (David \& Hayes, 2011). Likewise, Khalsa (2014) found yoga and medical meditation (transcendental meditation) as Alzheimer's prevention medicine. Khalsa prescribes four pillars of Alzheimer's prevention and maximize brain power and reduce the risk of the disease with this approach: 1) diet and brain-specific nutrients, 2) stress management 3) Physical and mental exercise, and 4) spiritual/psychological wellbeing. These almost all prescription can be linked to traditional practice of Sandhyopaasan.

Yoga and Medical Meditation ${ }^{\mathrm{TM}}$ as Alzheimer's Prevention Medicine. Mindfulness-based cognitive therapy shows promise in preventing recurrent depression (Stubenrauch, 2011). Hussain and Bhusan (2010) have divided meditation in two categories: 1) concentration meditation: it aims as single pointed focus on some sound, image or sensation to still the mind and achieve greater awareness. 2) transcendental meditation ${ }^{\mathrm{TM}}$ developed by Maharshi Mahesh Yogi in 1958. TM is generally done by focusing the mind on some mantra (sound) to achieve transcendental state of consciousness.

Mindfulness meditation on the other hand involves opening up or becoming more alert to the continuous passing stream of thoughts, images, emotions and sensations without identifying oneself with them. Such practice helps in developing non-reactive state of mind, which is the foundation for calm and peaceful state of consciousness.

\section{Defining Key Terminologies}

This paper defines "Sandhyopaasan" ritual as a compact combination of yoga, meditation and praying through Vedic perspective. This is a phrase which can be separated as Sandhya + Upasana. Sandhya means junctions of times they are moments of before rising the sun in the morning, forenoon of midday and before setting the sun in 


\section{6| Rajendra Raj Timilsina}

the evening. These transitions are called 'sandhi' (junction). Upasana means worshipping. Worshiping in the transitions are called as Sandhyopaasan. Definition by Acharya Kaundinnyanah (2066 Bikram Era) says: "these conjunctions are conjunctions of all Gods and Goddesses and thoughtful worshiping super being with liturgical is Upasanaa" (p.112).

Shri Swami Shivananda (1999) has explained the term as follow: Sandhyopaasan literally means 'worship at the junctions of time.' It is a prayer and worship offered to the Lord at the junction (Sandhi) of night and morning, forenoon and afternoon and at the junction of evening and night. The Arghyapradan to the sun and the meditation on and recitation of Gaayatree form, the heart of the worship. Properly understood, the whole Sandhya is an earnest prayer addressed to the Lord to forgive all one's sins committed during one's routine, daily activities and to bestow illumination and grace (www.dlshq.org/ download/hinduismbk.htm).

Paraphrasing the term, some people like to use 'Sandhya' only and some others say- 'Sandhyabandan'. Some of others 'Jap' in Nepal. Jap is a meditation part of Sandhyopaasan where Gaayatree mantra is recited. Many faithful Hindus at least perform 'jap' every morning and evening before having any food. Midday Sandhya has been found impractical in this era because of modern school and office systems. Sandhya is an obligatory duty to be performed daily for self-purification and self-improvement (http://hinduonline.co/ HinduReligion/AllAboutHinduism5.html).

Procedural definitions are adopted from the textbooks developed by the Government of Nepal (CDC, 2005 \& 2007) as well as Sandhyopaasan manual of Pokhara ChisakholaVeda Vidhyashram, Nepal, where pupils have been practicing daily.

Some of the major terminologies have been used as "Biniyoga","Mudra" and "Nyas" in between the processes of the ritual. "Biniyoga" or "Viniyoga" is used as a description of self order of a segment wise chanting of Mantra in religious rituals. Biniyoga is performed in Sandhyopaasan ritual several times. The performer takes some holy water $(j a l)$ in a spoon in right hand and says something about what he is going to do like chant a specific mantra and respective mantra's origin. Background of every mantra of Veda has Rishi (divinely inspired sage/poet), Chhanda (meter), 


\section{7| Rajendra Raj Timilsina}

Devata (deity) and purpose (Biniyoga).

\section{Purpose and Methods}

Aim of this paper is to explore how the root of present day yoga and meditation including transcendental meditation that can be traced in Sandhyopaasan in Hindu ritual. Nepal's Sandhyopaasan ritual which starts from education (Upanayan ritual) and goes life-long. That is practiced daily, twice a day or three times a day as the practiceners' convenience. The people have been practicing yoga, "mudra" and meditation in a compact daily package and this write up analyzes proximity among recent global practices.

This paper has used qualitative paradigm mainly participatory observation, interview, literature review and reflectivity to explore connection among the practice of Sandhyopaasan ritual with yoga as well as meditation. Professor emeritus of Nepal Sanskrit University Deergha Raj Ghimire (72); and, Patron of Chisakhola Veda Vidyashram, Pokhara, Nepal, Kedar Nath Upadhyaya (93), are main participants and my own self-reflection is another main source of data for analysis. Practices in Chisakhola Ashram, Pokhara; Guru Naranarayan Ashram, Mata Tirtha, Kathmandu; and Gargi Kanya Gurukul, Mali Gaun, Kathmandu have been observed. In addition, health related journals on yoga and meditation, books on Sandhyopaasan, Sandhyavandan, Mudra therapy, Meditation Gaayatree (Jap) and therapeutic yoga have been reviewed.

\section{Foundations of Sandhyopaasan}

There are 16 life rituals (sanskaaras) during pre-womb to post tomb in Hinduism. It is very hard to find strict practice of all of all 16 Vedic rituals in present day business. However, Birth, Annaprasan (rice feeding), Naamakaran (name giving), Chudakarma (Shaving of the head), schooling (Upanayana), marriage, death rituals have been performed traditionally in general. Acharya (2013) says parents are enemies who do not educate their child properly. So, they start writing with proper procedures of the ritual. This is a major celebration as we celebrate birth celebration and solid food feeding (Acharya, 2009). The child is made to worship to the picture of statue of Lord Ganesh (God of Success) and Saraswati (Goddess of learning). Then they worship pen/pencil, writing pad/wood plate and ink as well. This is literacy age and it might between 5 to 7 years. After beginning of 
study (pp. 220-237), Upanayan Sanskaar (formal education comencing ritual) is performed that is called "Bratabandha". In Bratabandha, the boy wears sacred thread "janai" (Yagyopabit) Sootra) in body and makes (Shikhaa) braid/crest over his head. These two are major signs of faithful Hindu. These are first qualifications for Sandhyopaasan. There are other practices which create invisible vibrations as well as they have been taken as daily eligibility for Sandhyopaasan.

\section{Daily Eligibility}

1. Pray on hands (Kara darsanam): The performers waken up and sit on the bed in early morning and chant some mantras and verses. The chanting give confidence and strengths because there is the divine power with the devotee whatever he does. This promotes internal peace and tranquility. Very much popular verse line (Shloka) which is one of the homage prayers to the deities from the bed is: ॐँ० कराग्रे वसते लक्ष्मी करमध्ये सरस्वती । करमूले स्थितो ब्रह्मा प्रभाते करदर्शनम् ॥ (Karagre basate laxmi karamadhye saraswati, kara mule sthito brahma prabhate karadarshanam). This mantra means: Laxmi (goddess of prosperity) sits in the fingertips, Saraswasti (goddess of learning) is on the palm, Brahma (creator of universe) sits on the root of the palm, it is auspicious to see and bow the hands in the morning. Reciting this Shlokaline performers rub and look own palms. Then they bow the hands. This practice builds confidence in the people on own hands.

\section{Pray to the Earth (Bhoomi Darshanam):}

The following pray is chanted with standing position ॐँ समुद्र वसने देवी पर्वतस्तनमण्डिते। विष्णुपत्नी नमस्तुभ्यम् पादस्पर्शम् क्षमस्वमे ॥ (Samudra vasane Devi, Parvata Stana Mandite, vishnupatnee namastubhyam, paada sparsham kshyamaswa mey). This mantra means: Oh! Mother Earth, who has the ocean as clothes and mountains and forests on her body, who is the wife of Lord Vishnu, I bow to you. Please forgive me for touching you with my feet.

\section{Pray for best object looking (Mangala Bastu Darshanam):}

ॐँ रोचनम् चन्दनम् हेम मृदंगम् दर्पणम् मणिम् । गुरुमगिन्म रविं पश्येन्नमस्येत् प्रातरेव हि ॥ (Oum rochanam chandanam hema mridanga darpanam manim, gurumagnim ravim pashyen namasyet praatareva hi). This mantra means: Oh my deities! I would prey ! color, red sandal wood, gold, Mridanga (a type of drum i.e. Madal), mirror, gem, guru, fire and sun can be seen in the morning. Then prayers of Ganesh, 
Bishnu, Shiva, Sun, Devi, Nawa Graha (Nine planetary gods), sages, nature with divine verses are chanted.

\section{Bathing (Snaanam):}

Bathing is prior essential for every worship, chanting and ritual in Hinduism. Early morning bath makes the human body pure as well as increases 12 things: charm, energy, strengths, purity, longevity, hygiene, health, virtue, benevolence, reality, penance, intelligence. People should go to the bathing spaces like well, pond, river, public tap and bathroom or any holy place. Before taking bath, there is a commitment procedure. Fresh cloths are put near the bathing space and hands and legs are washed first. Braid knot is made. Janai (Yagyopabit) of the body is taken in hand at its wearing position with water and the water is taken by palm to mouth that is called "aachaman". Citing Manusmriti, Shloka 60, Chapter 2, Mani (1975) translates "aachaman", "first drink water three times accompanied by incantations and then with water wipe your face twice and your eyes, ears, nose, shoulders, breast and head once". After aachaman, the person should express his statement of intent (Sankalpa) to preform the sandhya practice. In Sankalpa, water with Kush grass or mere water is taken in the palm and chanted some verses to point out the venue of ritual in the globe, country, district, village, tole, area and residence of the holy place, age, year, month, day, position of planets on the day, the actor's ancestral clan and linkages and name as well as purpose and the name of ritual is performing. The performer should always be updated on Vedic/Hindu calendar, situation of the planetary position according to astronomy, procreator's theology and recalled theosophy and theology of "Maha Purana". A sample Sankalpa for bathing in Kathmandu as follows:

हरिः ॐँ तत्सत् हरिः ॐँ तत्सत् हरिः ॐँ तत्सत् ॐँ विष्णुः ॐँ विष्णुः ॐँ विष्णु:

अद्येह श्रीमद्भगवतो महापुराणपुरुषस्य विष्णोराज्ञाया प्रवर्तमानस्य सकलजगत: सृष्टिकारिणो ब्रह्मणो द्वितीय परार्थे श्रीश्वेतवाराहकल्पे प्रह्लादाधिपत्ये मनौ सप्तमे वैवस्वतमन्वन्तरे सत्यत्रेताद्वापरान्ते बौद्धावतारे अष्टाविंशतितमे कलियुगे तस्य प्रथमचरणे भूर्लोके जम्बूद्वीपे हिमवत्वण्डे आर्यावर्ते गंगादेव्या उत्तरदिगभागे हिमाचलस्य दक्षिणपार्वे नेपालदेशे पाशुपत क्षेत्र पशुपते: काष्ठमण्डप: जनपदे ..... नाम्नि नगरे, ..... नाम्नि स्थाने ,..... निवासे इह पुण्य भूमौ षष्टिसंवत्सराणां मध्ये ...... नाम्नि संवत्सरे श्रीसूर्यनारायण ...... अयने ॠतौ ..... मासे ..... पक्षे ..... तिथौ ..... वासरे ..... राशिस्थिते श्रीसूर्ये ..... राशिस्थिते देवगुरौ ..... राशिस्थिते चन्द्रमसि, अन्येषु शेषेसु ग्रहेषु यथायथा राशिस्थानस्थितेषु सत्सु एवं ग्रहगणविशेषेण विशिष्टान्वितायां शुभपुण्यतिथौ ..... गोत्र:..... प्रवरः

अहं श्रुतिस्मृतिपुराणोक्तफलप्राप्तिपूर्वक श्रीभगवत्प्रीत्यर्थं नित्यकर्माइत्वेन प्रातः स्नानं करिष्ये । (Hari oum tatsat (3 times) oum vishnu (3 times) adyeha 


\section{0| Rajendra Raj Timilsina}

shimadbhagavato mahapuranapurushasya vishnoraagyayaa pravartamanasya sakala jagatah sristikaarino brahmano dwitiya paraardhe shreeshwetavaaraahakalpe prahladaadhipatye manau saptame vaivashwatamananwantare satyatretadwaaparaante baudhaawatare ashtaabimshatitame kaliyuge tasya prathama charane bhoorloke jambu dwipe himavatkhande aaryaavarte gangadevyaa uttaradigbhaage himaachalasya dakshina paarshwe nepaldeshe paashupatakshyetre pashupateh kaashthamandapah janapade ...naamni nagare, ... naamni sthaane, ... niwaase iha punya bhumau shashti sambatsharanaam madhye ... naamni sambatsare shreesooryanaaraayana ... ayane ...ritau ...maase ... pakshye,... teethau... baasare ... rashisthite shreesoorye ... raashisthite devagurau ... raashisthitechandramasi,... anyeshusheseshugraheshu yathaayathaa raashisthaanasthiteshu satsu yebam graha gana visheshena vishishtaanwitaayaam shubha punya teethau ... gotrah ... pravarah... aham shrutismritipuraanoktafalapraaptipurvakam shreebhagavat preetyartham nityakarmangatwena praata snaanam karishye). With this commitment, the water taken in the palm is lifted to the ground. After the Sankalpa, the pilgrimage of bathing is prayed as imagined as divine river Ganga which can liberate the person, the pilgrimage is as king, all divine places as father of the world, as king of all pilgrimages, all divine rivers. Chanting prayer with verses to Ganga's 12 names, she has committed to sit any sources of water where the devotees are going to take bath. The 12 names of Ganga which have been given in the verse are: Nandini, Nalini, Seeta, Maalatee, Mahaapagaa, Vishnupadabjasambhoota, Ganga, Tripathagaamini, Bhagirathi, Bhogavati, Janhavi, Tridasheswari.

ॐँ नमामि गंगे तव पादपंकज सुरासुरैव्वन्दितदिव्यरूपम् । भुक्तिं च मुक्तिं च ददासि नित्यं भावानुसारेण सदा नराणाम् ॥ (Namami gange tava padapankajam surasurairbanditadivyarupam, bhuktim cha muktim cha dadasi nityam bhabanusarena sadanaraanaam). त्वं राजा सर्वतीर्थानां त्वमेव जगत: पिता । याचितं देहि तीर्थं मे तीर्थराज नमोडस्तुते ॥ (Twam raja sarvateerthaanaam twameva jagatah pitaa, Yachitam dehi teerthammey teertharaja namostute). गंगे च यमुने चैव गोदावरी सरस्वती। नर्मदे सिंधु कावेरी जलेऽस्मिन् सन्निधिं कुरू। (Gange cha yamune chaiva godavaree saraswatitee, narmade sindhukaveree jalesmin sannidhim kuru). नन्दिनी नलिनी सीता मालती च महापगा। विष्णुपादाब्जसम्भूता गंगा त्रिपथगामिनी ॥ (Nandinee nalinee seeta maalatee chà mahaapagaa,

Vishnupaadaabjasambhuta ganga tripathagaaminee). भागीरथी भोगवती जाहनवी त्रिदशेश्वरी । द्वादशैतानि नामानि यत्र यत्र जलाशय । (Bhagirathee bhogavatee jaanhaviee tridasheshwaree, dwadashaita- 


\section{1| Rajendra Raj Timilsina}

ani namani yatra yatra jalashaya). स्नानोद्यत: स्मरेन्नित्यं तत्र तत्र वसाम्यहम् ॥ (Snaanodyatah smarennityam tatra tatra vasaamyaham). After praying the bathing place, the person starts bathing with chanting 5 Vedic mantras:

ॐँआपोऽअस्मान् मातरः शुन्धयन्तु घृतेन नो घृतप्व: पुनन्तु । विश्व हि रिप्रं प्रवहन्ति दे वीरुदिदाभ्य: शुचिरा पूतेडएमि ॥ (Oum aapoasmanmatarah sundhayantu ghritena no ghrtapwah punantu, visvam hi ripram pravahanti devirudidabhyah suchira putayemi).

ॐँ दीक्षातपसोस्तनूरसि तां त्वा शिवा शग्मां परिदधे भद्रं वर्णम् पुष्यन्। (Oum dikshyapasostanoorasi tam twa shivaa shagmam paridadhe bhadram varnam pukhyan).

ॐँ आपो हि ष्ठा मयो भव:स्ता नडऊर्जे दधातन। महे रणाय चक्षसे ॥ (Oum aapo hi shtha mayo bhuvahsta na oorje ddhatana, ranaya chakshyase).

ॐँ यो व: शिवतमो रस:। तस्य भाजयतेह नः । उशतीरिव मातरः। (Oum jyo vah shivatamo rasah, tasyabhaahayatehnah. ushateeriva matarah). ॐँ तस्मा अरं गमाम वो यस्य क्षयाय जिन्वथ। आपो जनयथा च नः॥ (Oum tasmaaaram gamaama vo yasya kshyayaya jinwatha, aapo janayathaa cha nah).

ॐँ पुनन्तुमा देवजना: पुनन्तु मनसा धिय: । पुनन्तु विश्वा भूतानि जातवेदा पुनीहि मा " (Oum punantuma bevajanah punantu manasaa dhiyah, punantu vishwa bhutaani jaatavedaa puneehimaa). After chanting and bathing, the devotee prays to Lord Vishnu:

ॐँ शान्ताकारम् भुजगशयनम् पद्मनाभम् सुरेशम् । विश्वाधारम् गगनसदृशम् मेघवर्णम् शुभाइ्गम् ॥ लक्ष्मीकान्तम् कमलनयनम् योगिभिर्ध्यानगम्यम् । वन्दे विष्णुम् भवभयहरम् सर्वलोकैकनाथम ॥ (Oum shaantaakaaram bhujaga shayanam, padma naabham Suresham, vishwaa dhaaram gagana sadrisham, megha varnam shubhangam, laxmi kantam kamala nayanam, yogibhir dhyana amyam, vande vishnum bhava bhaya haram sarva lokai kanaatham).

Completion of bath and changing the pure/holy dress, the person offers libation (तर्पण), a pouring out of water in honor of a deities from his right hand's front part or through "arghyapaatra", a small pot for libation. Actually, this is flower water. This libation has taken as a part of bathing. Most of the people pouring out the water only in unavailability of flower or Kush grass. Some of the devotees use paste of sandal wood (chandan), akshyata (teeka) and leaf of basil (tulasipatram) for the libation. The following mantras are chanted looking toward east direction while performing libation each time canting one mantra from in front of the palm (deavteertha):

ॐँ ब्रह्मादयो स्तृप्यन्ताम् । (Oum brahmaadayo stripyantam) (This offering 


\section{2| Rajendra Raj Timilsina}

of libation is devoted to God of creation Brahma).

ॐँ भूर्देवास्तृपयन्ताम् । (Oum bhoordevaastripyantam) (This offering of libation is devoted to Gods of earth).

ॐँ भुवर्देवास्तृप्यन्ताम् । (Oum bhuvardevaastripyantam) (This offering of libation is devoted to Gods of universe).

ॐँ स्वर्देवास्तृप्यन्ताम् । (Oum swardevaastripyantam) (This offering of libation is devoted to Gods of space).

ॐँ भूर्भुव: स्वर्देवस्तृप्यन्ताम् । (Oum bhoorbhuvah swardevaastripyantam) (This offering of libation is devoted to Gods of earth, universe and space). After libation offering to gods from fingers side of the palm (Devateertha), libation starts to sages (Rishis) from left side of the right palm (Kaayateertha).Yagyopabit is turned to neck and taking Kush grass, libation is devoted twice in each mantra looking toward north direction:

ॐँ० सनकाद्वैपायनान्ता ऋषयस्तृप्यन्ताम् ।

(Oum sanakadwaipayananta rishayastripyantam) (This offering of libation is devoted to sages including Sanak, Dwaipayan, Ananta and others).

ॐँ भूतष्टयस्तृप्यन्ताम् । (Oum bhoorishayastripyantam) (This offering of libation is devoted to sages of earth).

ॐ भुवत्ॠषयस्तृप्यन्ताम् । (Oum bhuvarishayastripayantam) (This offering of libation is devoted to sages of space).

ॐ स्वत्रषयस्तृप्यन्ताम् । (Oum swarishayastripyantam) (This offering of libation is devoted to sages of space).

ॐँ भूर्भुवस्वत्ॠषयस्तृप्यन्ताम् । (Oum bhoorbhuvaswarishayastripyantam) (This offering of libation is devoted to sages of earth, universe and space). Then, the performer's face turns to south direction, uses place of palm in between thumb and first finger (Pitriteerth) in pouring water three time in chanting to beginning ancestors with each mantra as libation as follow:

अ कव्यवाडनलादय: पितरस्तृप्यन्ताम् । (Oum kavyavadanaladaya stripyantam) (This offering of libation is devoted to ancesters including Kavyavadanala and others).

ॐँ भू: पितरस्तृप्यन्ताम् । (Oum bhooh pitarastripyantam) (This offering of libation is devoted to fathers of the earth).

ॐ० भुव: पितरस्तृप्यन्ताम् (Oum bhuvah pitarastripyantam (This offering of libation is devoted to fathers of the universe). ॐँ० स्व: पितरस्तृप्यन्ताम् । (Oum swah pitarastripyantam) (This offering of libation is devoted to fathers of the space). 


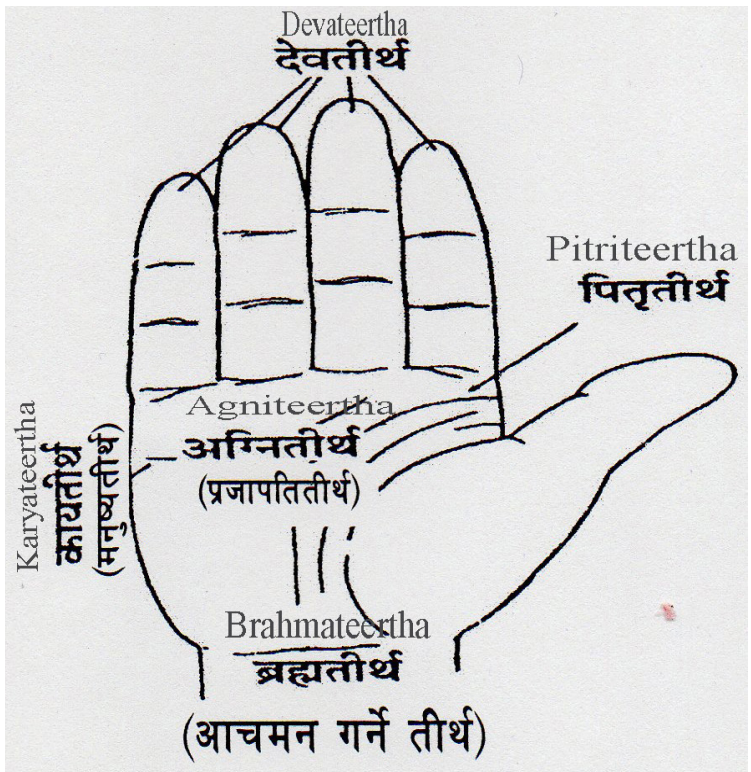

Figure 1: Picture of the palm during libation

ॐँभूर्भुवस्व: पितरस्तृप्यन्ताम् । (Oum bhoorbhuvahswah pitarastripyantam) (This offering of libation is devoted to fathers of the earth, universe and space). Then janai or yagyopabit is turned to normal position of the body that is called 'savya' and aachman is done. Then water with sesame seeds is taken in right palm and mantra as follow is chanted: ॐँ यन्मया दूषितं तोयं शारीरमलसंभः । तस्य पापस्य शुद्धयर्थ यक्ष्मैतत्तेतिलोदकम् ॥ (Oum yanmayaa dooshitam toyam shaarira malasambhaveh). (Meaning: Whatever I polluted the water from my body, to liberate from that $\sin$, I have offered the libation of water with sesame seeds). The water and the seeds is sprinkled around the banks of the pilgrimage. Another mantra is chanted while braid of the performer is wringer vine of surrounding of the pilgrimage:

लतागुल्मेषु वृक्षेषु पितरो ये व्यवस्थिता:। ते सर्वे तृप्तिमायान्तु मयोत्सृष्टै:

शिखोदकै: ॥ (Lataagulmeshu vrikshyeshu pitaro ye vyavasthotah, te sarve triptimayantu mayotsrishtyaih shikhodakaih) (Meaning: All trees and vines which are managed by ancestors may content from water of my braid.). This is completion of the procedure of bathing (snaanam). Some people do Sandhyopaasan near at the water sources and others perform at their own worshiping space of residence or private temple/home temple. Generally, the performer returns to residence and enters to the worshipping spot where materials for 
Sandhyopaasan are set. There is one grass made mattress for sitting, two copper cops with copper spoons, water pots, and suser. He sits on the mattress and expresses his commitment (Sankalpa) taking water in the right palm. Reciting age, time, period, continent, place, ancestral linkages and date and others as it was recited in bathing. Different is the work "Sandhyopaasan" instead of "Snaan". The procedures follow the sankalpa.

\section{Procedural Steps of Sandhyopaasan:}

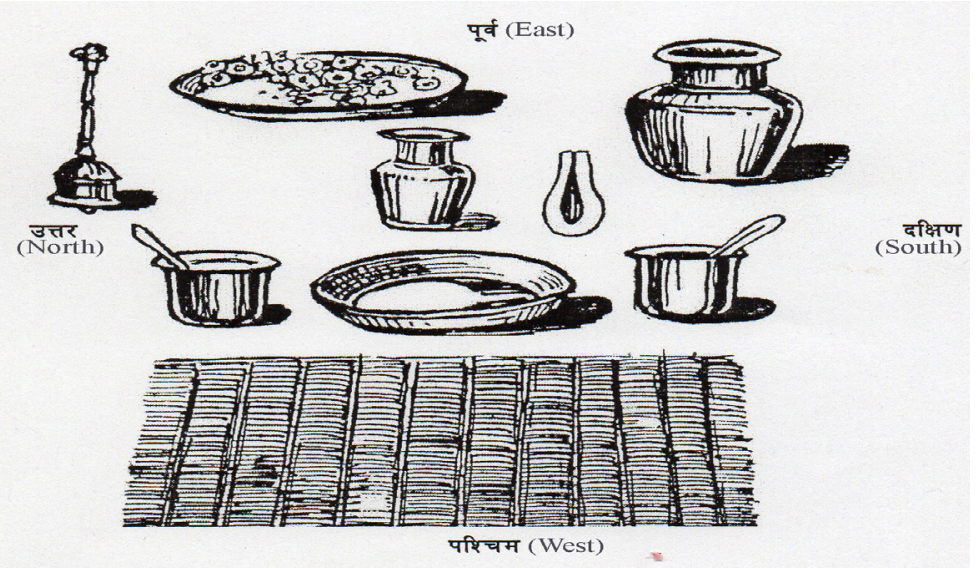

Figure 2: Sandhy aa materials सन्ध्या सामग्री

\section{A) Purification of seat (Aasan suddhi):}

Seat is purified by chanting mantra each session of sandhyopaasan. Biniyoga is performed before chanting mantra: अँ पृथिवीति मन्त्रस्य मेरुपृष्ठ ऋषि: सुतलं छन्द कूर्मो देवता आसने विनियोग: (Oum prethiviti mantrasya merupristha rishih sutalam chhanda koormo devataa aasane biniyigah). A spoon of water is left on the ground and the mantra is chanted. The mantra is:

ॐँ पृथ्वी ! त्वया धृता लोका देवि ! त्वं विष्णुना धृता । त्वं च धारय मां देवि ! पवित्र कुरु चासनम् " (Oum prethivi ! twayaa dhretaa lokaa devi! twam vishnunaa dhretaa, twam cha dhaaraya maam devi! pavitram kuruchaasanam). Reciting the mantra water is sprinkled on the seat. This is pray to the earth.

\section{B) Pasting Teeka of ashes on forehead and body (Bhasma/Tilak dharanam):}

Ashes is taken by right hand from a pot to left palm and a drop of water is mixed and the ash is converted to paste. During the course, 


\section{5| Rajendra Raj Timilsina}

this mantra is chanted: ॐँ अग्निरित भस्म, वायुरिति भस्म, जलमिति भस्म, स्थलमिति भस्म, व्योमेति भस्म, सर्व गूँ हवा इदं भस्म एतानि चक्षंषि भस्मानि ॥ (Oum Agniriti bhasma, vayuriti bhasma, jalamiti bhasma, sthalamiti bhasma,vyometi bhasma, sarva goon idam bhasma yetani chakshunkhi bhasmaani). The ashes is blessed by another mantras: ॐँ त्र्यम्बक यजामहे सुगन्धिम् पुष्टिवर्धनम् । उर्वारुकमिव बन्धनान् मृत्योर्मुक्षीय मामृतात् ॥ (Om tryambakam jyajamahe sugandhim pushtivardhanam, urvaarukamiva bandhanaan mrityormukshiya maamritaat).

ॐँ प्रसद्य भस्मना योनिमपश्च पृथिवीमग्ने । स गूँ सृज्ज्यमातृभिष्ट्वं ज्ज्योतिष्मान् पुनर सद: ॥ (Oum prasadya bhasmana jyonimapashcha prethivimagne, sa goon srejjyamaatribhishtwan jjyotikhman punaraasadah). Now, the ashes is pasted to forehead, neck, chest, arms and wrists with this mantra:

ॐँ० त्र्यायुषज्जमदग्ने : कश्यपस्य त्र्यायुषम् । यद्देवेषु त्र्यायुषं तन्नोऽअस्तु त्र्यायुषम् " (Oum tryaayukhanhamadagnehe kashyapasya tryaayukham, jeddevekhu tryaayukam tannoastitraayukhamma). The ashes is prepared by special process of firing and purification which is antiseptic/antibiotic for health as well as warm for body because is covers the holes of hair of the body parts, Yogis say. According to Christian missionary doctor Richard Charlick, "ashes are strong bacteria killer" (2010, p. 85).

\section{C) Wearing finger ring of Kush (Pavitra dhaaranam):}

Kush ring is already made and the mantra is chanted while that is wearing as the divine ornament helps to fulfill the desires of the deotee:

अनन्तगर्भिणं साग्रं कौशं द्विदलमेवच । प्रादेशमात्रं विज्ञेयं पवित्रं यत्र कुत्रचित् ॥ (Anantauarbhinam saagram kausham dwidanameva cha, praadehshamaatram vigyeyam pavitram yatra kutrachit). ऊँ पवित्रेस्थो वैष्णव्यौ सवितुर्वः प्रसवडउत्पुनाम्यच्छिद्रेण पवित्रेण सूर्यस्य रश्मिभिः । तस्य ते पवित्रपते पवित्रपूतस्य यत्कामः पुने तच्छकेयम् ॥ (Oum pavitreshtho vaishnavyau saviturvah prasava utpunamyachhidrena pavitrena soorjyasya rashmibhih, tasya te pavitrapate pavitrapoota;ya jyetkamah pune tachhakeyamma).

\section{D) Knotting the Braid (shikhabandhanam):}

Shikha (braid) is knotted with these mantras: ${ }^{\circ}$ मानस्तोके तनये मा नऽआयुषि मानो गोषु मानोऽअश्वेषरीरिषः । मानोव्वीरान् रुद्रभामिनो व्वधीर्हविष्मन्तः सदमित्त्वा हवामहे ॥ (Oum Maanastoke tagaye maa na aayukhi maano gokhu maano ashwekhureerikhah, maanovveeran rudrabhamino 
vvadhirehavikhmantah sadamitwa havamahe). $3^{\circ}$ चिद्रूपिणि महामाये दिव्यतेज: समन्विते । तिष्ठ देवि शिखाबन्धे तेजोवृद्धिं कुरुष्व मे ॥ (Oum chidrupini mahamaye divyatejah samanwite, tishtha devi shikaabandhe tejovriddhim kurushwa mey). Scholars of religion as well as Ayurveda have explained shikhaa's scientific reasons: A) A person who keeps shikha attracts cosmic energy which imparts enlightment. (B) The small portion of hair that hangs from behind our head applies little pressure on our brains that helps one to improve concentration and mind control and improve memory (http://www.indiadivine.org/ why-do-hindus-wear-the-tuft-of-hair-called-shikha).

\section{E) Sipping of water (Aachamanam):}

A spoon of water is put in the right palm and sip three time reciting 3 Vedas respectively: ॐ ॠग्वेदाय स्वाहा। ॐ यजर्वेदाय स्वाहा । स्वाहा । (Oum rig vedaya swaha, oum yajur vedaya swaha, oum saama vedaya swaha). Then the palm is washed by another spoon of the water by mantra of $3^{\circ}$ अथर्ववेदाय नम:I (Oum atharva vedaya namah).

\section{F) Exercise of breathing (Praanayaam):}

Before exercising of breathing, biniyoga is done because the exercise is to perform reciting the Vedic mantra. ॐँ० प्रणवस्य ब्रह्मात्रषि: अगिन्देवता दैवीगायत्रीछन्द: सप्तानाम् व्याहततीनामं ऋमेण विश्वामित्रजमदग्निभरद्वाजगौतमात्रिवसिष्ठकश्यपा ऋषय: अगिनवायुसूर्यबृहस्पतिवरुणेन्द्रविश वेदेवा देवता: गायत्र्युष्णिगनुष्टुब्बृहतीपंक्तिस्त्रिष्ट्ब्जगत्यश्छन्दांसि, तत्सवितुरित्यस्य विश्वामित्रत्ॠषि: सवितादेवता गायत्रीछन्द: आपोज्योतिरित्यस्य प्रजापति ऋषि: ब्रह्माग्निवायुसूर्यदेवता यजुश्छन्द: सर्वेषां प्राणायामे विनियोग: ॥ (Oum pranavasya brahmarishihi agnirdevataa daivigaayatrich handah saptanam vyahritinam kramena vishwamitrajamadagnibhara dwaajagautamatrivasishthakashyapaa rishayah agnivaayusooryabrihaspativarunendravbishwedeva devatah gaayatruishniganushtubbrihateepanktistristubjagatyashchhandaamshi, tatsaviturityasya vishwaamitrarishihi savitaa devataa gaayatrich handah aapojyotirityasya prajapatirishihi brahmagnivaayusooryadevataa yajushchhandah sarvesham praanaayame biniyogah).

After Biniyoga, the mantras are recited silently while praanayaam is done: ॐ० भू: । (Oum bhooh). ॐ० भुव: । (Oum bhuvah). ॐ० स्व: । (Oum swah). ऊँ मह । (Oum mahah). ॐँ जन: । (Oum janah). ॐँ तप: । (Oum tapah). ॐँ सत्यम् । (Oum satyam). ॐँ तत्सवितुर्वरेण्यम् ...। (Oum tatsaviturvarenyam...). ॐँ आपो ज्योती रसोमृतं ब्रह्म भूर्भुव: स्वरोम ॥ (Oum aapo jyotee rasomretam brahma bhoorbhuvah swarom). These mantras are keeping in the mind for concentration and breathing is exercised. There are three steps for practice of praanaayama: poorak, kumbhak, 


\section{7| Rajendra Raj Timilsina}

and rechak. Poorak is inhalation of breath, rechack is exhalation of breath and kumbhak is retention of breath. These are repeated as per willingness of the performer. Some spent 3 minutes and others spent more minutes. These are main practice of praanayaam is time duration is upon the yogi. This is yoga part of the sandhyopaasan. Same mantra is chanted in different purpose and biniyoga announces the purpose and context of chanting the mantra accordingly.

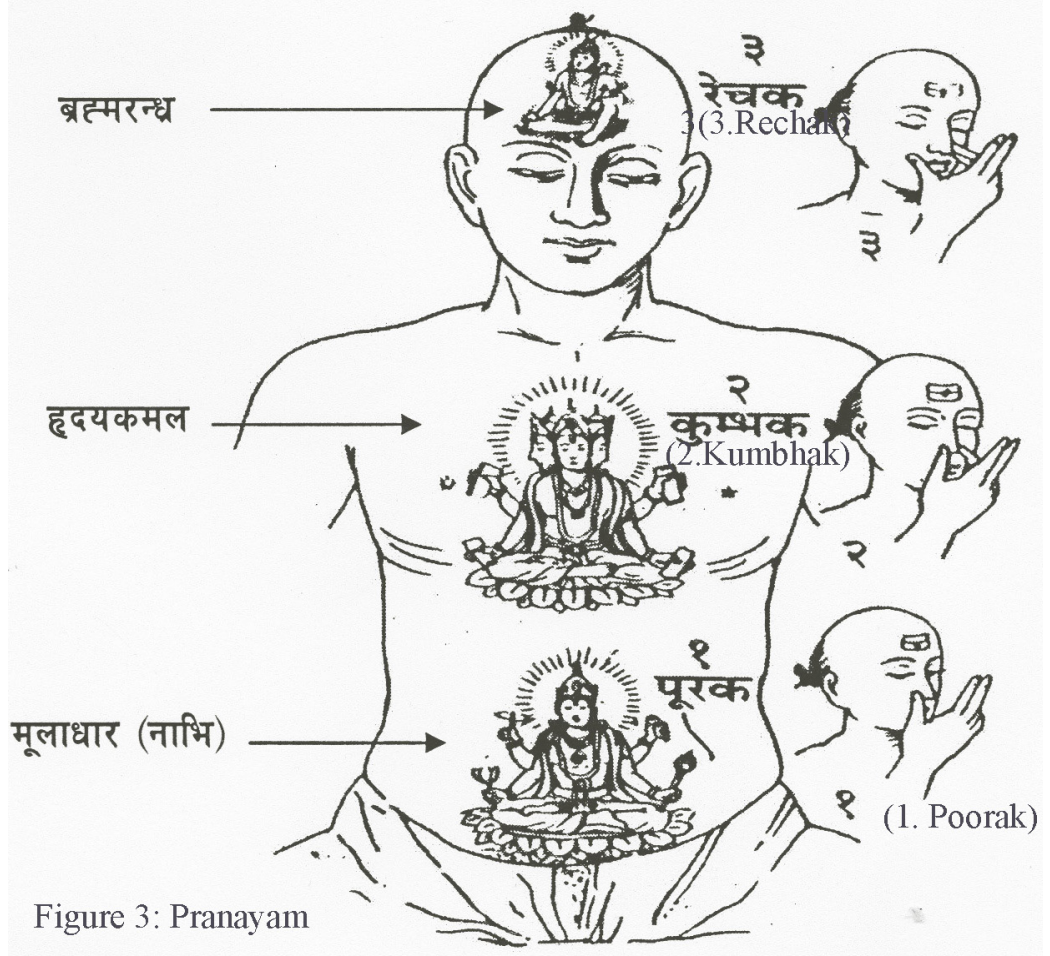

G) After the exercise, aachaman is done.

\section{H) Purification (outer) (marjanam):}

Water is taken in left palm and dipping the two middle fingers of the right hand in it, water is sprinkled with using right thumb to different organs of the body. Some people use kush for sprinkle and some use 3 middle fingers as they intend. The sprinkling of water on the face and the head and the touching of the different organs (the mouth, nose, eyes, ears, chest, shoulders, head, etc.) with wetted fingers, are meant to purify those parts of the body and invoke the respective presiding deities on them. They also stimulate the nerve-centres and 
wake up the dormant powers of the body.

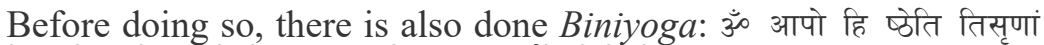
सिन्धुद्वीपत्टषि: आपो देवता गायत्री छन्द: मार्जने विनियोग:। (Oum aapo hi shtheti tisrinam sindhudwiparishihi aapo devata gaayatree chhandah maarjane biniyogah). Water is sprinkle to different own organs including head with this mantra: ${ }^{\circ}$ आपो हि ठठ मयो भुवः। ${ }^{\circ}$ ता न ऊर्जे दधाचन। ॐ० महेरणाय चक्षसे। ॐ० यो व: शिवतमो रस:। ॐँ तस्य भाजयते ह नः । ॐँ उशतीरिव मातरः । ॐँ तस्मा अरं गमाम व:। ॐँ० यस्य क्षयाय

जिन्वथ । ॐ० आपो जनयथा च न: । (Oum aapo hi shtha mayo bhuvah, oum taa na oorje dadhaachana, oum maha ranaaya chakshyase, oum jyo vah shivatamo rasah, oum tasya bhaajayateh nah, oum ushatireeva maatarah, oum tasma aram gamam vah, oum jyasya kshyayay jinwatha, oum aapo jana yathaa cha nah).

\section{I) Purification (Inner) (Aghamarshanam):}

Water is taken in the palm and right nostril inhales the oxygen of the water to the breathing with chanting Vedic mantra. This is like another type of praanayaam with water smell. Before reciting the mantra, here is also biniyoga: ॐँ० द्रुपदादिवेत्यस्य कोकिलराजपुत्र ॠषि: आपो देवता अनुष्टुप्छन्द: अघमर्षणे विनियोग: ॥ (Oum drupadaadivetyasya kokilarajaputra rishihi aapo devataa anushtup chhandah aghamarshane biniyigah). This "Aghamarshan" process destroys the proud form of sin remained in the body and the person is eligible to Gaayaatree meditation. Aghamarshan mantra is: ${ }^{\circ}$ द्रुपदादिव मुमुचान: स्विन्नः स्नातो मलादिव । पूतंपवित्रेणेवाज्यमाप: शुन्धन्तु मै नस: ॥ (Oum drupadadiva mumuchaanah swinnah snato maladiva, pootampavitrenevajyamaapah shundhantu mainasah).

\section{J) Libation to the Sun God (Sooryarghya):}

This is performed after aachaman. There is also step of biniyoga: ॐँ भूर्भुव: स्वरिति महाव्याहततीनां परमेष्ठी प्रजापतिऋषि: अगिनायुसूर्या देवता: गायत्र युष्णिगन्ट्टुभ्श्छन्दांसि, तत्सविसतुरित्यस्य विश्वामित्र ॠषि: सवितादेवता गायत्रीछन्द: अघ्र्यदाने विनियोग: । (Oum bhoorbhuvah swariti mahavyahritinam parameshthi prajapatirishihi agnivaayusooryaa devatah gayatryushniganushbhchhandamsi, tatsaviturityasya vishwamitra rishihi savitaadevataa gaayatrich handah arghyadane biniyogah). Holy water with flower or kush grass is in a pot as Arghya in Sandhyopaasan and the Arghya is dedicated to the Sun god.

Gaayatree mantra is recited as: ॐँ भूर्भुव: स्व: तत्सवितुर्वरेण्यं। भर्गो देवस्य धीमहि, धीयो यो न: प्रचोदयात् ॥ (Oum Bhoor Bhuvah Swah, Tatsaviturvarenyam, Bhargo Devasya Dhimahi, Dhiyo jyo Nah Prachodayat). Arghya offering is done three times with dedication verse of इदमर्घ्यं समपयामि 
भगवते ब्रह्मस्वरुपिणे सूर्यनारायणाय नम:। (Idamarghyam samarpayami Bhagavatebrahmaswarupine sooryanarayanayanamah). Thisoffering mantra is used for morning oblation where as "Vishnuswarupine" in the noon and "Shivaswarupine" in the evening is called instead of "Brahmaswarupine" of the morning. Form of Sun is changed in the different tome peroid and the dedication addresses the exact form.

\section{K) Experiencing the nearness to God (Sooryopasthanam):}

The devotee performs this segment in standing position with raising hands to middle stage of front side to the Sun. This is also followed by biniyoga for all four mantras: ॐँ उदूयमुदुत्यमिति दूयो प्रस्कण्वत्रषि: सूर्योदेवता अनुष्टुप्छन्द:, चित्रंदेवानामित्यस्य कुत्साड़िरस ऋषि: सर्योदेवता त्रिष्टुप्छन्द:, तच्चक्षरित्यस्य दध्यड्डाथर्वणत्रषि: सर्योदेवता उष्णिक्छन्द: सर्योपस्थाने विनियोग:। (Oum udvayamudutyamiti dwayo praskanwarishihi sooryodevata anushtupchhandah, chitrandevanamityasya kutsaangirasa rishihi sooryodevata trishtupchhandah, tachchakshyurityasya dadhyangaatharvana rishihi sooryodevata ushnikchhandah sooryopasathane biniyogah). Meanings of mantras show the real power of people extracted from the sun. The mantras are: ${ }^{\circ}$ उदूयन्तमसस्परि स्व: पश्यन्तऽउत्तरम् । देवन्देवत्रा सूर्यमगन्म ज्योतिरुत्तमम् । (Oum udwayamtamasaspari swah pashyanta uttaram, devandevatra sooryamaganma jyotiruttamam). Meaning: O Supreme Sustainer ! We visualize Thee in the upper quarter of space. O Saviour! Protect us from the diseases and pains which tends to increase. Thou art Omniscient: help us to acquire true wisdom so that our ignorance may be eliminated. May sympathy and co-operation prevail in our society.

ॐँ उदुत्यं जातवेदसं देवं वहन्ति केतव: । दृशे विश्वाय सूर्यम् ॥ (Oum udutyam jaatvedasam devam vahanti ketavah, dreshe vishwaya sooryam). Meaning: O Supreme Progenitor ! Thou hast revealed the divine knowledge in the form of the Vedas. Thou art the Supreme Impeller of our intellectual faculties. May Thy Grace encourage us to obtain right knowledge and to learn good manners. Consequently, may we

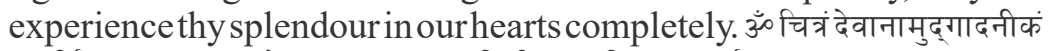
चक्षुर्मित्रस्य वरुणस्याग्नेः । आप्रा द्यावापृथिवी अन्तरिक्षऽम् सूर्य आत्मा जगतस्तस्थुषश्च स्वाहा ॥ (Oum chitram devagamudagaadanikam chakshyur mitrasya varunasyagneh, aapra dyavaprethivi antarikshyamma soorya aatmaa jagatastasthukhashcha). Meaning: O God ! Thou artour praiseworthy spiritual strength. Thou enlightens our intellectual faculties. OAll-pervading God! We have experienced thy motivating power, in the absence of which no particle of the universe can move. We pray 


\section{0| Rajendra Raj Timilsina}

to Thee to show us the right path, by following which we can make our lives sublime. O gracious God! May we realize thy true self in our hearts.

ॐँ तच्चक्ष्र्देवहितं पुरस्ताच्छुक्रमुच्चरत्। पश्येम शरद: शतं जीवेम शरद: शतम् शृणुयाम शरद: शतं प्र ब्रवाम शरद: शतमदीना: स्याम शरद: शतं भयश्च शरद: शतात् ॥ (O Oum tatchakshurdevahitam purastaatchchhukramuchchrat. Pashyema shradah shatam jeevema shadah shatam shrenuyama sharadah shatam pra bravama sharadah shatamadinaah syama sharadah shatam bhuyashch sharadah shatat). Meaning: O Self-effulgent God! Thou, existing ever and everywhere, are the supreme guide and benefactor of the animate world. May we, by the grace, live for a hundred years, with the full span of life, with perfect mental and corporal health. May we become fortunate enough to have Thy Division vision, to hear and speak Thy Sacred Word, the Vedas. We pray most humbly to Thee to furnish us with healthy organs, noble thoughts and economic prosperity.

The Suryopasthanam or prayer to the Sun has found scientific reason as gaining Vitamin D. This prayer is similar to "Chhath" festival where people worship the rising and setting Sun twice a year (After Tihar festival and after Holi festival) mostly in Terai area (Southern plains). Throwing/offering water or Arghya (plain water or yogurt mixed recipe) to the Sun has been found some result to skin disease and peace of mind as well. This is similar to daily Suryopasthan too. Chanting suryopasthaan mantras take almost 3 minutes. During this chanting the devotee raises hands as surrender to the Sun God. This step is performed as the devotee whether does Sandhyopaasan in noon and evening as well. According to Mani (1975), the Upasthan mantras are chanted in standing position looking to the Sun. However, many devotees found performed all procedure in worship/meditation/yoga room. Some of them sit for other procedure after completing the standing prayer with chanting.

\section{L) Gaayatree-six-organs Self healing (Gaayatree Shadanga Nyas):} The devotee exercises for energy through own fingers moving to the body remembering goddess Gaayatree. In Nyas, firstly five fingers of right hand is performed: ${ }^{\circ}$ भू: अडुष्ठाभ्याम् नम:। (Oum bhooh angushthabhyaam namah). Right thumb is folded. अ भुव: तर्जनीभ्याम् नम:। (Oum bhuvah tarjanobhyam namah). Index finger is folded. ॐँ स्व: मध्यमाभ्याम् नम: । (Oum swah madhyamabhyam namah). Middle finger is folded. ऊँ० तत्सवितुर्वरण्यम् अनामिकाभ्याम् नम:। (Oum tatsaviturvarenyam anaamikaabhyaam namah). Ring finger is folded. $ँ$ भर्गो देवस्य धीमहि कनिष्ठिकाभ्याम् नम:। (Oum bhargo devasya 


\section{1| Rajendra Raj Timilsina}

dheemahi kanishthikabhyaam namah). Baby finger is folded and all fingers of the hand are folded. ${ }^{\circ}$ धियो योन: प्रचोदयात् करतलकरपृष्ठाभ्याम् नम:। (Oum dhiyo jyonah prachodayat karatalakaraprishthabhyaam namah). Both palms are touched as Namaste figure and they are made opposite posture of Namaste.

Secondly, organ Nyas is performed. The finger are used to get divine energy using the finger in touching different six organs. ॐँ भू: हदयाय नम:। (Oum bhooh hridayaya namah). Right hand touches the chest (heart). ॐँ भुव: शिरसे स्वाहा । (Oum bhuvah shirase swaha). The hand is put on the head. अं० स्व: शिखायै वषट् । (Oum swah shikhayai vakhat). Other fingers are folded and thumb touches the head vertically. तत्सवितुर्वरेण्यम् कवचाय हुम् । (Oum tatsaviturvarenyam kavachaaya hum). Both hands are crossed to shoulders to cover the chest. $3^{\circ}$ भर्गो देवस्य धीमहि नेत्रत्रयाया वौषट् । (Oum bhargo devasya dheemahi netratrayaaya vaukhat). Thumb and baby fingers are folded and other three fingers are put on two eyes and forehead (mid brow) at the same time while eyes are closed. ॐँ धियो योन: प्रचोदयात् अस्त्राय फट्। (Oum dhiyojyonah prachodayat ashtraaya phat). Group of the three middle fingers of right hand clap to the left palm which creates a clapping sound as well. Gaayatree mantra's fragmented portions commencing with "OUM" are chanted in each step and this spiritual self healing (Nyas) method in creating self energy from own body.
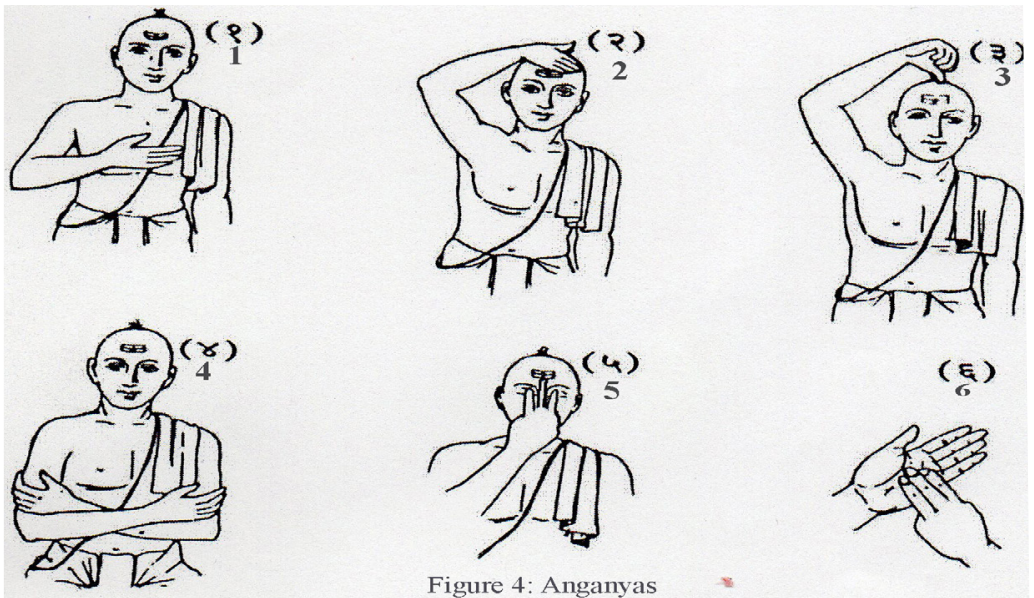

Figure 4: Anganyas

\section{M) Invitation to Gaayatree (Gaayatryavaahanam):}

Before chanting the invitation mantra, biniyoga is done: 


\section{2| Rajendra Raj Timilsina}

तेजोसीत्यस्य परमेष्ठी प्रजापतिर्त्रषि: आज्यं देवता जगती छन्द: यजुर्गायत्र्यावाहने विनियोग: । (Oum tejoseetyasya parameshthee prajaapatirrishihi aajyam devataa jagatee chhandah yajurgaayatryaavaahane biniyogah). The mantra is: ॐँ तेजोसि शुक्रमस्यमृतमसि धामनामासि प्प्रियन्दे वानामनाधृष्टन्देवयजनमसि । (Oum tejosi shukramasyamretamaasi ppriyandevaanaamanaadhreshtagdevayajanamasi).

N) Pray for near to Gaayatree (Gaayatryupasthaanam): Biniyoga is done before chanting the pray mantra:

ॐ० तुरीयपदस्य विमल ऋषि: परमात्मा देवता गायत्री छन्द: गायत्र्युपस्थाने विनियोग: । (Oum turiyapadasya vimala rishihi paramatma devataa gaayatree chhandah gaauatryupasthaane biniyogah). Mantra for the pray: ॐँ गायत्र्यस्ये कपदी द्विपदी त्रिपदी चतुष्पद्यपदसि न हि पद्यसे । नमस्ते तुरीयाय दर्शताय पदाय परोरजसेडसावदोमा प्रापत् ॥ (Oum gaayatryasyekapadi dwipadi tripadee chatushpadyapadasi na hi padyase, namaste turiyaaya darshataaya paraaya paro rajase saavadomaa praapat).

\section{O) Gaayatree meditational pray (Gaayatreedhyaanam):}

This meditation pray describes the features of the goddess Gaayatree: ॐँम मुक्ताविदुमहेमनीलधवलच्छायैर्मुखैस्त्रीक्षणैर्युक्तामिन्दुकलानिबद्धमुकुटां

तत्वात्म वर्णात्मिकाम् । गायत्रीं वरदाभयाड्रुशकशा शुभ्रं कपालं गुणं शह्द्रंचक्रमथारविन्दयुगलं हस्तै वहन्तीं भजे ॥ (Oum muktaavidrumahe maniladhavalachchhaayairmukhaistrikshyanair yuktamindukalaanibaddhamukutaam tatwatmavarnaatmikaam,Gaayatreem varadaabhayaankushakashaa shubhram kapaalamgunam, shankham chakramathaaravindayugalam hastairvahantim bhaje). Meaning of the pray: Goddess Gaayatree's five faces are white like pearl; one is red like coral, second is yellow like gold, third is blue like neelam, fourth white like milk, and the fifth is of 'trinetra' or three eyed. We meditate her gem studded headgear with half- moon like jewel on her head, and eight hands with benedictine mudras, 'Ankusam', Gada (mace), Sankham, Chakram, Skull, and two lotuses.

There are separate pray according to time of Sandhyopaasan. Different verses of pray to Gaayatree for morning, noon and evening additionally. Meaning the chantings describes as her gesture, posture, attire and power as assuming by the devotee; and the description of the pray find almost similar as presented above meaning.

For morning pray: ब्रह्माणी चतुराननाक्षवलयं कुम्भं करै: स्रुक्स्तुवौ बिभ्राणारुणकाी 


\section{3| Rajendra Raj Timilsina}

न्तरिन्दुवदना ऋरुपिणी बालिका ॥ हंसारोहणकेलिरम्बरमणेर्बिम्बाज्चिता भूषिता । गायत्री हुदि भाविता भवतु न: सम्पत्समृध्यै सदा ॥ (Brahmaanee chaturaananaakshyavalayam kumbham karaih sruksruvau, bibhraanaarunakaantirinduvadanaa rigrupini baalikaa; hfmsaarohanakelirambaramanerbimbaanchita bhooshitaa, Gaayatree hridi bhaavitaa bhavatu nah sampatsamridhyai sadaa).

For noon pray: रुद्राणी नवयौवना त्रिनयना वैयाघ्रचर्माम्बरा ।

खट्वाड्गत्रिशिखाक्षसूत्रवलयाभीतिर्दधानाम्बिका ॥ विद्युत्पुज्जजटाकलापविलसद्बालेन्दुमौलि: सदा । सावित्री वृषवाहना सिततनुर्ध्येया यजूरूपिणी ॥

(Rudraani navayauvanaa trinayanaa vaiyaaghracharmaambaraa, khatvangatrishikhaakshyasootravalayaabhitirdadhaanaambikaa; vidyutpunjajataakalaapavilasadbaalendumaulihi sadaa, saavitree vrishavaahanaa sitatanurdhyeyaa yajooroopinee).

For evening pray: वृद्धा नीलघनप्रभापरिलसत्पीताम्बरा भूषिता ।

दिव्यैराभरणैरथाड्गकमले शड्द्ध गदां बिभती॥ तार्क्षस्कन्धगता समस्तजगदाराध्या परा वैष्णवी। ध्येया चैव सरस्वती भगवती सामस्वरूपा सदा ॥ (Vriddhaa neelaghanaprabhaaparilasatpeetaambaraa bhooshitaa, divyairaabharanairathaangakamale shankham gadam bibhati; taarkshyaskandhagataa samastajagadaaradhya paraa vaishnavee, dhyeyaa chaiva saraswatee bhagavatee saamaswaroopa sadaa).

\section{P) Pray for Gaayatree's redemption from curse (Gaayatree- Shaapavimochanam):}

Gaayatree was cursed by Brahma (creator of the universe) and sages duo Vashishtha and Vishwaamitra, according to different Puranic epics. The curses are taken as obstacle in achieving the proper bless from the goddess. So, devotees of Gaayatree perform pray for redemption from the curses before commencing Gaayatree meditation. Sandhyopaasan procedure follows the same steps. The performer pray for the curses with Biniyoga and mantras. brahmashapvimochanam: ॐ० अस्य श्रीब्रह्मशापविमोचनमन्त्रस्य ब्रह्मा ॠषिर्भिक्तिमुक्तिप्रदा ब्रह्मशापविमोचनी गायत्रीशक्तिर्देवता गायत्री छन्द: ब्रह्मशापविमो चने विनियो ग:। (Oum asya shreebrahmashaapvimochanamantrasya brahma rishirbhuktimuktiprada brahmashapvibicahani Gaayatreeshatirdevataa gaayatree chhandah brahmashaapvimocahane Biniyogah). Mantra:

ॐ० गायत्रीं ब्रह्मेत्युपासीत यद्रुपं ब्रह्मविदो विदु:। तां पश्यन्ति धीरा: सुमनसो वाचमग्रत: ॥ ॐँ० वेदान्तनाथाय विद्महे हिरण्यगर्भाय धीमहि तन्नो ब्रह्म प्रचोदयात् । ॐँ देवि ! गायत्रि ! त्वं ब्रह्मशापाद्विमुक्ता भव ॥ (Oum Gaayatreem brahmetyupasita yadrupam brahmavido viduh, tam pashyanti dheerah sumanaso vaachamagratah; Oumvedantanaathaaya vidmahehiranyagarbhaya 


\section{4| Rajendra Raj Timilsina}

dheemahi tanno brahma prachodayat. Oum devi!

gaayatree! twam brahmashaapaadvimukta bhava). Biniyoga for Brahmashaapavimochana mantra: ऊँ अस्य

श्रीवसिष्ठशापविमोचनमत्त्रस्य निग्रहानुग्रहकर्ता वसिष्ठ ऋषिर्वसिष्ठानुगृहीता गायत्रीशक्तिदे 'वता विश्वोद्भवा गायत्री छन्द: वसिष्ठशापविमोचनार्थम् जपे

विनियोग:। (Oum asya shreevashishthashaapavimochanamantrasya nigrahaanugrahakartaa vasishtha rishirvasishthanugrihita gaayatreeshaktirdevataa vishwodbhavaa gaayatree chhandah vasishthashaapvimochanartham jape biniyogah). Mantra: ॐ0 सोऽहमर्कमयं ज्योतिरात्मज्योतिरहं शिव: । आत्मज्योतिरहं शुक्र: सर्वज्योतीरसोऽस्म्यहम् ॥ (Oum sohamarkamayam jyotiraatmajyotiramshivah, aatmajyotiram shukrah sarvajyotirasosmyaham). Reciting the mantra the devotee should show a gesture of feminine organ by using hands' fingers and recite Gaayatree mantra three times. Then to say: ॐँ० दे वि ! गायत्रि ! त्वं वसिष्ठशापाद्विमुक्ता भव । (Oum devi ! gaayatree ! twam vasishthashapadvimuktaa bhava).

Vishwamitrashaapavimochanam (विश्वामित्रशापविमोचनम्):

Biniyoga: ॐँ अस्य श्रीविश्वामित्रशापविमोचनमन्त्रस्य नूतनसृष्टिकर्ता विश्वामित्रत्रषिर्विश्वामित्रानुगृहीता गायत्री शक्तिर्देवता वागदेहा गायत्री छन्दः विश्वामित्रशापविमोचनार्थं जपे विनियोग: । (Oum asya shreevishwaamitrashaapvimochanamantrasya nootanasrishtikarta vishwamitrarishirvishwamitraanugriheeta gaayatree shaktirdevataa vaagdehaa gaayatree chhandah vishwaamitrashaapavimochanartham japebiniyogah). Mantra: ${ }^{\circ}$ गायत्री भजाम्यगिनमुखी विश्वगभां यदुद्भवाः । देवाश चक्रिरे विश्वसृ( ष्टिं तां कल्याणीमिष्टकरी प्रपद्ये॥ (Oum gaayatree bhajaamyagnimukhee vishwagarbham yadudbhavah, devaashchakrire vishwasrishtim taam kalyaanimishtakarim prapadye). ऊँ देवि ! गायत्रि ! त्वं विश्वामित्रशापाद्विमुक्ता भव । (Oum devi! gaayatree! twam vishwamitrashaapaadvimuktaa bhava). Compact pray for all the three: ऊँ० अहो देवि महादेवि संध्ये विद्ये सरस्वति ! अजरे अमरे चैव ब्रह्मयोनिर्नमोडस्तु ते ॥ (Oum aho devi mahaa devi sandhye vidye saraswati, ajare amare chaiva brahmayonirnamastute). ॐँ दे वि ! गायत्रि ! त्वं ब्रह्मशापाद्विमुक्ता भव, वसिष्ठशापाद्विमुक्ता भव, विश्वामित्रशापाद्विमुक्ता भव । (Oum devi ! gaayatree ! twam brahmashaapaadvimukta bhava, twam vasishthashapadvimuktaa bhava, twam vishwamitrashaapaadvimuktaa bhava).

\section{Q) Gesture expression (Mudra Pradarshanam):}

Mudra literally means 'gesture' and it expresses and channelizes cosmic energy within the mind and body (http://users.tpg.com.au/ 


\section{5| Rajendra Raj Timilsina}

shrein/yoga/information/mudra.pdf). Sandhyopaasan practiceners chant verses about 24 names of the mudras and express the actitivities of fingers: सुमुखं सम्पुटं चैव, विततं विस्तृतं तथा । द्विमुखं त्रिमुखं चैव चतुष्पन्चमुखं तथा ॥ षण्मुखा धोमुखं चैव व्यापकाज्जलिक तथा। शकटं यमपाशं च ग्रंथितं सन्मुखोन्मुखम्॥प्रलम्बं मुष्टिक चैव मत्स्यकूर्म वराहकम् । सिंहाक्रान्तं, महाक्रान्तं, मुद्गरं, पल्लवं तथा ॥ एता मुद्राश्चतुर्विंशज्जापादौ सम्प्रदर्शयेत् ॥ (Sumukham samputam chaiva, vitatam vistritam tatha, dwimukham trimukham chaiva chatuh panchamukham tatha; shadmukha adhomukham chaiva vyaapakanjalikam tatha, shakatam yamapaasham cha granthitam sanmukhonmukam; pralambam mushtikam chaiva matsyakoorma varahakam, simhakrantam mahakrantam mudgaram pallavam tatha. Eta mudrashchaturvimshajjapadau sampradarshayet).

Likewise, hands as well as fingers' movement is performed that is called "Nyas". Firstly, hand "Nyas" is done where fingers are exercised each other systematically with chanting mantras. Then, six organ "Nyas" is done touching heart by right hand, touching forehead, head, closing the hands, closing eyes by fingers and three fingers' pose touches the left palm finally in the 6 organ Nyas (ShadangaNyas). After Nyas, Gaayatree is prayed and called for meditation. Nyas is followed by Mudra. Then some sages are remembered with mantras. Then 24 types of fingers' signs is performed. 24 gestures are expressed in this segment:

a. Sumukham: Consolidate all fingers of both hands and toutch the groups of the fingers each other.

b. Samputam: Make meet all half folded fingers and make a shape of closed pot.

c. Vitatam: Stand both palms paralelly.

d. Vistritam: Make more distance from Vitatam.

e. Dwimukham: Touch root of both palms and touch the top of the small fingers and ring fingers so that two mouth like gesture is seen.

f. Trimukham: Add middle fingers in Dwimukham gesture.

g. Chaturmukham: Add index finger in Trimukham.

h. Panchamukham: Add thumb in Chaturmukham.

i. Shadmukham: Open both small finger in the position of Panchamukham.

j. Adhomukham: Make the palms oposite and make down.

k. Byaapakaanjalikam: Show the palms to the front.

l. Shakatam: Fold three fingers and touch thumbs each and keep open index fingers.

m. Yamapaasham: Make a knot of index fingers with closing other fingers. 

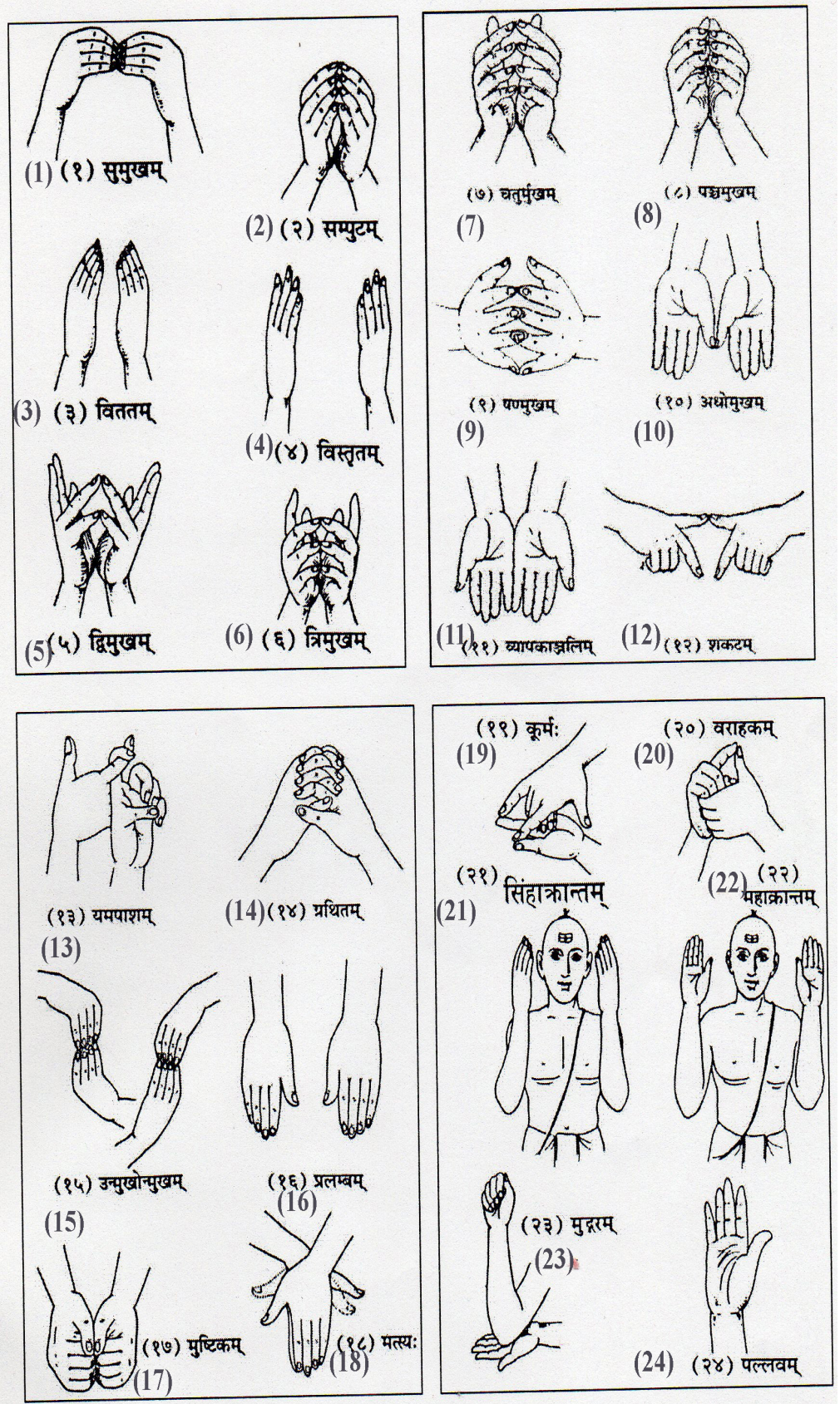

Figure 5: 24 Hands Gestures 


\section{7| Rajendra Raj Timilsina}

n. Grathitam: Join all fingers of both hands each other tightly.

o. Unmukhonmukham: Collect all fingers separatly in each hand and put up and down moving each other the group of the finger top parts.

p. Pralambam: Slightly fold fingers and show both hadns to down separately but parallelly.

q. Mushtikam: Mix both fists tied.

r. Matsya: Put right palmer over left dorsal and move thumbs like gesture of fish.

s. Koorma: Bend all the fingers except the thumb and the little fingers) and hold the palms tight like tortoise.

t. Baraahakam: Right index finger to haunt met to left thumb with crossing both hands fingers.

u. Simhaakraantam: Take the fingers of both hands near the ears.

v. Mahakraantam: Stand both hands near the ears.

w. Mudgaram: Place the left hand on the right elbow and turn the fist.

x. Pallavam: Wave right hand infront of face like modern leaders.

R). Gaayatree japa/jap (Meditation on the name of Gaayatree): ॐ० प्रणवस्य ब्रह्मा ऋषि: परमात्मा देवता गायत्री छन्द:, व्याहतीनां प्रजापतिऋषि: अगिनायुसूर्या देवता: गायत्री छन्द:, तत्सवितुरित्यस्य विश्वामित्र ऋषि: सविता देवता गायत्री छन्द: सर्वपापक्षयार्थे गायत्रीमन्त्रजपे विनियोग:। (Oum pranavasya brahmaa rishihi paramatama devataa gaayatree chhanda vyaahritinaam prajapatirishihi agnivayusoorya devataah gaayatree chhandah tatsaviturityasya vishwamitra rishihi; savitaa devataa gaayatree chhandah sarvapaapakshyaarthe gaayatree mantrajape biniyogah).
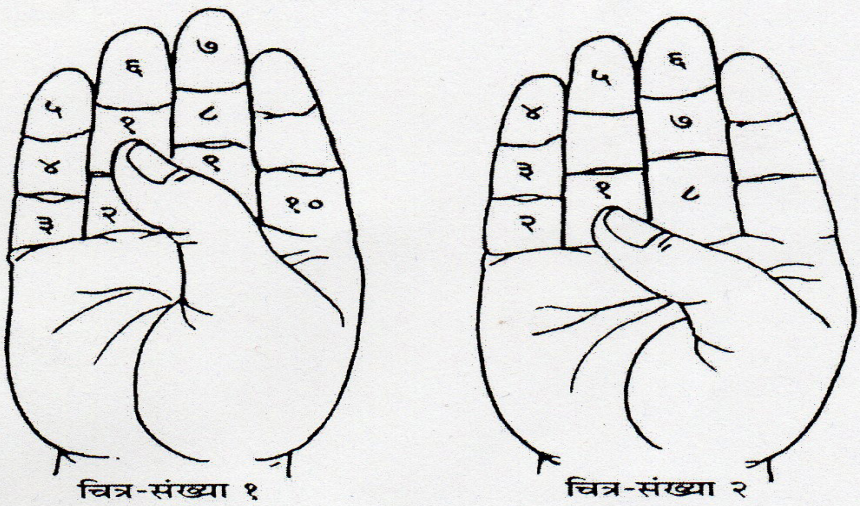

Figure 6: Karmaalaa

After biniyoga, aachaman is performed for the jap. Meditation on 


\section{8| Rajendra Raj Timilsina}

the name of Gaayatree is Gaayatree japam. Counting is done silently. Some people count the silent praying of repetition by own fingers of right hand and others use prayer beads (maalaa). The japam only 10 times is general jap of Sandhyopaasan. It is done 24, 54, 108 or 1008 times. The pictures of palm presented above are for counting Gaayatree mantra 108 times. The silently reciting mantra is:

\section{ॐँ भूर्भुव स्वः। तत् सवितुर्वरण्यं। भर्गो देवस्य धीमहि । धियो}

योन: प्रचो दयात् ॥ (Oum bhoorbhuvahswah tat saviturvarenyam ! bhargo devasya dhee mahi dhiyo jyo nah pracho dayat!!). The mantrais preceded by three sacred expressions, the Mahavyahritis 'the great utterances'. It is called Guru mantra: because, firstly, it conveys a great sense, secondly, it is employed by the preceptor to initiate a pupil. It is also named as Gaayatree mantra: because firstly, it protects the reciter from ill-intentions and secondly, it belongs to the Gaayatree class of metres (composed of 23 or 24 syllables excluding the vyahritis). According to the subject matter of the mantra, it has been given the name of Saavitri.

\section{Meaning of Gaayatree mantra:}

O Omnipotent God! thou are our dearest life-breath. Keep us away from evil intentions and physical sufferings. May we ever have thy pure vision in over mind. O divine Enlightener ! Lead kindly light to us. May Thy splendor-nature direct our minds towards the righteous path. May we attain not only physical progress but also the ultimate emancipation. (Vedalankar, 2014, p. 57).

However, Gaayatree mantra for Kshetreeya and Baishya are diffrent (CDC, 2014). For Kshetriya: ॐ० देव सवित: प्रसुव यज्ञ प्रसुव यज्ञपतिं भगाय । दिव्यो गन्धर्व: केतपू: केतं न: पुनातु वाचस्पतिर्वाजं न: स्वदतु ॥ (Oum deva savitah prasuva jyanyam prasuva jyanyapatim bhagaaya, divyo gandharvah ketapoohu ketam nah punatu vaachasparirvaajam nah swadatu). For Baishya: अँ विश्वा रुपाणि प्रतिमुन्चते कवि: प्रासावीद् भद्रं द्विपदे चतुष्पदे । विनाकमख्यत्सविता वरेण्योडनुप्रयाणमषसो विराजति ॥ (Oum vishwaa roopani pratimunchate kavihi praasaaveed bhadram dwipade chatushpade, vinaakamakhyatsavitaa varenyoanuprayanamukhaso viraajati). Pronunciation of the Vedic mantras are slightly different than written because Vedic grammar is different and signs have been used between alphabets. Guru is a must for proper pronounciation. So, the Hindus perceive the guru as god a mantra is chanted at the end of the Sandhyopaasan which means guru is Brahmaa, Vishnu, Maheshwar (Shiva) and the guru is real super god. In practice, very few people are aware about different Gaayatree mantras. Even, Dalits have been chanting Brahma Gaayatree. Pandits say, the Hindu Dalits 


\section{9| Rajendra Raj Timilsina}

follow all Hindu rituals but without mantra. Some Dalits found chanting all mantras as well. Padam Lal Biswakarma, the former chairperson of National Dalit Commission claims as Brahman on the ground of knowledge equal to Pandits. Aachaman is followed by Gaayatree jap. Then post jap mudra exercise is exhibited.

\section{S) Post jap mudra expression (Uttaraanga mudra pradarshanam):} Averse is chanted which calls the names of the mudras: सुरिज्ञानवैराग्यम् योनि: शंखोऽथ पड़जम । लिड्गम् निर्वाणकम् चैव जपान्तेऽष्टौ प्रदर्शयेत् ॥ (Surabhirgyana vairagyam yonihi shankhotha pankajam, lingam nirvanakam chaiva japanteshtau pradarshayet). These eight gestures are also made by fingers:

1. Surabhi: Make a gesture of four nipples of cow, cross joining fingers of both hands.

2. Gyanam: Meditation gesture but one hand is put on chest.

3. Vairaagyam: meditation gesture as similar as Gautam Buddha.

4. Yonee: Making shape of female organ using fingers of both hand.

5. Shankha: Catch left thumb by right palm and fingers and join left index finger to right thumb so that gesture is seen as crunch.

6. Pankajam: Make gesture like lotus using both touched palm standing fingers to up.

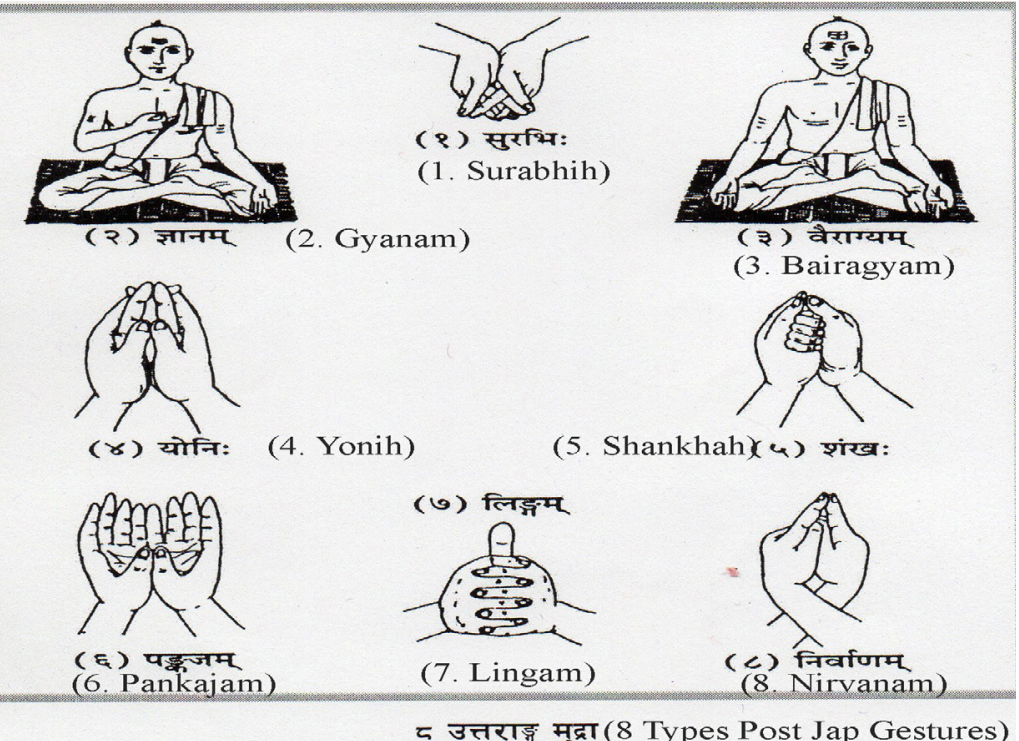

Figure 7: Post-Jap Gestures

7. Lingam: Make joint fist of both hands mixing all finger while right thumb is up as male organ. 
8. Nirvaanam: Cross hands each other vertically and make touch index finger as well as thumbs simultaniously.

\section{T). Oblation of water (Jala samarpanam):}

There is also biniyiga before chanting mantra: अं० देवागातु विद इत्यस्य मनसस्पतिश्रषि: वातो देवता विराट छन्द: जपनिवेदने विनियोग: । (Oum devaagaatu vida Ityasya manasaspati/rishihi vaato devataa viraat chhandah japanivedane biniyogah). Mantra: ॐँ देवा गततुविदो गततुं वित्तवा गततुमित । मनसस्पतऽइमन्देव यज्ञाँ सूाहा वातेधा:॥ (Oum devaa gaatuvido gatum vittwaa gaatumita, manasaspata Imandeva jyanya gun swaahaa vaatedhaah). This is request for accept the jap whatever number was counted that is committed to the Sun that is in the form of Brahmaa in morning, form of Shiva in noon and form of Vishnu in the evening is also mention in the chanting: अनेन प्रात:/ मध्याहन:/सायं सन्ध्याइ्नूते न (अमुकसंख्याकेन) गायत्रीमत्त्रजपाख्येन कर्मणा श्रीभगवान् ब्रह्मस्वरुपी/शिवस्वरुपी/ विष्णुस्वरुपी श्रीसूर्यनारायण: प्रीयताम् न मम ॥ (Anena pratah/madhyahnal saayam sandhyang bhutena (amuka sankhyakena) gaayatree mantra japakhyena karmana shreebhagavaan brahmaswarupi/shivaswarupi/vishnuswarupi shreesooryanaaraayanah preweyataam na mama). Meaning: This morning/noon/evening Sandhyopaasan's segment of Gaayatree jap has been dedicated to respective form of the sun god. Pray to Gaayatree: यदक्षरपदभ्रष्टं मात्राहीन तु यद्भवेत् । तत्सर्वं क्षम्यतां देवि काश्यपप्रियवादिनि ॥ (Yadakshyara padabhrashtam maatraaheenam tu yadbhavet, tatsarvam kshyamyatam devi kaashyapa priyavaadini). This is confession and please pardon me if there could have been some alphabetical errors while performing the procedures.

\section{U). Ending of the Sandhya (Sandhya visarjanam):}

Biniyoga: ${ }^{\circ}$ उत्तरे शिखरे इत्यस्य कश्यप ॠषि सन्ध्यादेवता अनुष्टुप् छन्द: सन्ध्याविसर्जने विनियोग:। (Oum uttare shikhare ittyasya kashyaka rishi sandhyaa devataa anushtup chhandah sandhya visarjane biniyogah). This is menifestation of farewell of Gaayatree and the Sandhyopaasan. Mantra: ऊँ उत्तरे शिखरे देवि भम्यां पर्वतमस्तके । ब्राह्मणेभ्यो विनिर्मुका गच्छ देवि यथासुखम् ॥ (Oum uttare shikhare devi bhoomyaam parvata mastake, brahmanebhyo vinirmukta gach ha devi yathaa sukham).

Then releasing of braid with chanting mantra: ब्रह्मपाशसहस्रेण रुद्रशूलशते न च । विष्णुचक्रसहस्रेण शिखामुक्ति करोम्यहम् ॥ (Brahmapaasha sahashrena rudra shoola shatena cha, vishnu ckakra shahashrena shikhaa muktim karomyaham). 


\section{1| Rajendra Raj Timilsina}

Finally, soil from front venue of the seat is taken and put on the forehead with this mantra: ${ }^{\circ}$ तत्सवितुरवरेण्यम् भर्गो देवस्य धीमहि धियो यो न: प्रचोदयात् । (Oum tatsavitur varenyam bhargo devasya dheemahi dhiyo jyonah pracho dayaat).

Interpreting 'Aitareya Braahmana' (a philosophical branch of Rig Veda) Pandya (2010, p.5) says being the source of ultimate evolution and beatified salvation of 'Prana' (the breath of life), the Aadi Shakti (initial power) is called Gaayatri. In other words, which protects the 'gaya' (prana) is Gaayatree. Similarly, the author has cited the scholarly Sankaracharya Bhashya (interpretation) in further explaining the meaning of Gaayatree as: the discerning, pure intellect 'Ritambharapragya', which unfolds the ultimate truth and absolute knowledge, is Gaayatree. Pronunciation is crucial in vedic ritual and yagyas. Pronounce of Internet record of the mantra is not Vedic pronunciation as I know from its originality. Because, there is separate formula of Vedic mantras pronunciation which is different from post-Vedic Sanskrit pronunciation. There is another step for Mudra showing again. There are eight types. Knowledge, detachment, crunch, lotus, sexual organs and nirvana also shown by the sign as well. Then, again Gaayatree is prayed with repeated confession whether some grammatical and other errors were occurred. and it goes to concluding pray. At this juncture, knot of braid is released and soil of the land is touched.

\section{Concise Method}

Concise method of Sandhyoapsan includes bathing, changing the clean cloth, Suryoapasthan and doing the jap. Jap means reciting the Gaayatree mantra minimum 10 times. There is no need of garland of Rudrakhya for counting. Because only 10 times of Gaayatree meditation has been taught to count with in fingers of right hand. Professor Deergha Raj Ghimire said in an interview the whole processses of praanayaam, and nyas is not neccessary. In the short cut method, bathing, arghya to the Sun, sooryopasthan (prayer of sun, experiencing the nearness to Sun God) and chanting Gaayatree mantra (jap) is a must. Other segments of Sandhyopaasan is optional.

\section{Discussion}

'Sandhya' is time of union or conjunction and there are three sandhya in a day: morning, noon and evening. The suffix 'Upasana' means 


\section{2| Rajendra Raj Timilsina}

praying or performing. Bandhan has same meaning "upasana". There are procedural or step-wise differences between Shukla Yajurveda and Krishna Yajur Veda on Sandhyopaasan/SandhyaBandhan. However, philosophy, meditation and yoga parts are similar. Iyer and Shastri (1930) on Krishna Yajurvedic or others's Shukla Yajurvedic practice of Sandhyopaasan has same aim: purity, perfection and discipline.

Sandhyabandhanam is a Nitya-karma, i. e., a karma the performance which a meritorious, and the non-performance of which is sinful. The first thing is that a Dwija has to do after he leaves his bed in the morning before day-break is to answer the calls of nature, clean his teeth and bathe in the orthodox fashion, and, after wearing dry cloths, to put on his Pundhra (teeka) or caste-mark. The next thing is the performance of the sandhyabandhanam, the importance of which cannot be overrated. After the night's sleep the mind is perfectly clear, and it is only right and proper that the first impressions that the mind receives should be such as will elavate a man intellectually, morally and spiritually. The sandhyavandanam is ordained by the Shrooti or Vedas. (https://archive. org/stream/ SandhyavandanaBhashyam\#page/n28/mode/1up). Puranas and educational pedagogies including Yaagyavalkya Smriti have been developed as invisioned by Upanishads which are metaphysics of Veda. Rootly, Taitteriya Upanishad and Taitteriya Aaranyaka originated Sandhyopaasan ritual has foundations of wearing of Yagyopavita (janai), a sacred thread. The sacred thread is for Brahman, Chhetri and Baishya castes. The three are twice born castes who get second birth or rebirth with Upanayana Sanskaar (sacred thread wearing ceremoney).This thread is found as knot for disciplined lifestyle. Similarly, the sun or light has much importance. Iyer and Shastri (1930) have linked the ritual with peace of mind of the people: Arghya Pradaana or the throwing up the holy water in the morning, the noon and the evening, and the Dyana or the meditation of Paramatman are specially enjoined by certain texts. The performance of the Sandhyavandana ending with the Dhyana is declared by the texts to be productive of the highest happiness or bliss. Shah (2006) explores Yoga has therapeutic treatment for endochrinology which has related to hormone.

In 1970s, Maharshi Mahesh Yogi, an Indian origin physicist who developed transcendental meditation and established Maharshi University of Management in USA had said "Nepal can lead the world". I have been observing his folowers' events in Kathmandu 


\section{3| Rajendra Raj Timilsina}

for some years and watching the quotation of the Yogi. All his transcendental meditation looks like a course which is taught on the day of Upanayan in Hindu society. Reciting Gaayatree mantra repeatedly and chanting mantra of Veda that is Rudrabhishekh (worship of Lord Shiva) have been emphasized as main part of transcendental meditation. Sandhyopaasan is almost the same. The Sandhyopaasan performer does the Rudrabhishek each morning in his prayer room as I used to do regularly myself from the age of 7 to 20 .

Yoga, meditation, transcendental meditation, Vipasysana meditation, Zen meditation, Kirtan Kriya of finger movement all have been found for mental engagement and peace. The Vedic compact course of Sandhyopaasan has mixture of almost all practices like: breathing, finger movement, deep concentration (jap or meditation).

Sandhyopaasan is Nitya karma (regular duty) of a person. Ones' work of other worshiping is not valid without Nitya Karma, though that might be done as concise methods. The concise method should have at least bathing, wearing fresh cloths, sprinkle the water to the Sun as Argyya, Praanayaam (Poorak, Kumbhak, Rechak) and Jap (meditation with Gaayatree mantra at least 10 times). Tentatively 10 minutes have spent for the concise practice of Sandhyopaasan. This is pragmatic for the faithful Hindus who are known as twice born castes. They recite the Gaayatree mantra secretly/silently despite their inconvient situation.

On the other hand, there is a provision of mental Sandhyopaasan as well. First, Sun God prayer (Suryopasthan) and Gaayatree meditation (Jap) are performed silently/mentally for 13 days if they are in grief on demise of their beloved. Second, such mental Sandhyopaasan is performed till 11 days if there is new birth in their family clan. Third, the mental Sandhyopaasan is valid while the faithful person is unhealthy condition. This is most liberal provision of Hinduism which also create mental engagement of spirituality for health, happiness and peace.

Changing context of professional shifting, development of office system, modern school system (Acharya, 2066 B. E.) has affected Sandhyopaasana of noon. It is very hard to find the noon practice of Sandhyopaasan. It is almost disappeared. Evening practice is also found decreasing. The morning Sandhyopaasan has been 


\section{4| Rajendra Raj Timilsina}

given continuity even that practice in concisely. The Hindus recite Gaayatree mantra as a secret power as participants reflected me. I have tallied the on-the-spot practices of Nepali Vedic schools to Chakravarthy (2010), Government of Nepal (2065 B. E. \& 2069), http:/hinduonline.co/HinduReligion/AllAboutHinduism5.html, and, Mishra (2003) step by step. Veda Guru Kedar Nath Upadhyaya of Chisaakholaa Ashram is totally healthy at the age of 93, still performs all processes of Sandhyopaasan every morning himself first and teaches Sandhyopaasan to boys as he taught me where I learnt in my childhood. Waking up early in the morning, taking bath though the water might be chilling; changing fresh sacred dress and conducting ritual is foundation of Vedic education. Specifically, faithful Hindus follow it. Upadhyaya has been running the Vedic school under his patronage and has been formalizing it in the name of mainstreaming religious education policy of the government of Nepal. This gurukul or habitus of guru (Awasthi, 2004) has been slightly modified in teaching learning processes. However, Sandhyopaasan is foundation of the education system. Sanskrit shool system which is moderate Vedic school, adopts the Sandhyopaasan courses at grade 9 where as it adopts from grade 6 in Veda Vidhyasharams/Gurukuls in contemporary Nepal.

So far the segment of fingers' exercise, the finger folding activities called "Mudra" (posture). According to a book of "Mudra Therapy" (http://users.tpg.com.au/shrein/yoga/information/mudra.pdf) the finger yoga has been taken as treatment of several problems of body. In Puranas, Gods and Goddesses expressed in different Mudras. Mudras are the expression of our inner feeling. Such mudra are done till two months of illness as stated in the book. The five fingers represent five elements (pancha tatwa) of the universe. They represent: Thumb =fire, Index finger $=$ air, Middle finger $=$ space, Ring finger $=$ earth and small finger $=$ water. When fire element goes weak, various ailments come to the body and death sets in when the fire element dies. Joining the fire element (thumb) with other elements (other fingers) vitalizes the other elements, according to the notion. For example: "Lingam" mudra stops production of phelgm and gives power to lungs, cures severe cold bronchial infection, invigorates the body. This mudra creats heat in the body. If this mudra done for longer, can cause sweating even in winter, "Mudra Therapy" warned. Performers of the Sandhyopaasan have been found benefitting from such self energy. 


\section{5| Rajendra Raj Timilsina}

These are not only finger exercise but they express whole pragmatism of the world. Mantras are chanted. Then, the devotee goes to silence with repeating Gaayatree mantra. Minimum 10 times to maximum thousands times the Gaayatree mantra is recalled silently. This is meditation. Meditation is the only solution discovered by the ancient Vedic masters for the suffering of the world. (Swami Chandresh, 2010, p.114). Deepest and longer practice of Gaayatree mantra is seem Transcendental meditation named by Maharshi Mahesh Yogi. This meditation technique consists of silently repeating a mantra with gentle effortness while sitting comfortably with eyes closed and without assuming any special yoga position. The mantra is not to reveal to others. The mantra is said to be a vehicle that allows the individual's attention to travel naturally to a less active, quieter style of mental functioning. Gaayatree mantra is the prayer for the virtuous intellect which is recited. Meditate on its sense and pray to God for the attainment of the virtuous intellectual faculties.

Anthropologist Victor Turner's lininality (neither this nor that) can be linked as conjunction time frame of Sandhyopaasan that is neither full day nor fully dark, neither afternoon nor morning but noon are the time of completion of the ritual. During Chhath festival is another example of worshiping the Sun. The Sun is prayed in the ending season of hot and ending season of cold (twice a year). Rising and setting sun is worshipped with water is vital in the festival as well. Turner (1979) analises such rites as liminality and can be found in all cultures, and are seen as both indicators and vehicles of transition from one sociocultural state and status to another. In Hinduism, this is taught in the liminal stage of childhood to maturity of the boys and they prepare themselves for self healing as well as self control for life long. Obviously, Sandhyopaasan has root of discipline, healing, controlling, and engaging self. Mainly, it has science of climatic position of the nation/s like Nepal. They get vitamin " $D$ " from the natural solar. Day and night time have almost same in Nepal. Each day is good day and there is no need of consuming the vitamin " $D$ " as isolated capsule or tablet.

On the other hand, the title is an example of anthropological perspective of purity and impurity as explainned by Mary Douglas (1966). The performers feel danger in their life if that is not made pure through habit of daily bathing and changing clean dress each time. 


\section{Conclusion}

A system of inherited conceptions has been tied up in symbolic forms Sandhyopaasan ritual by means of which people communicate, perpetuate, and develop their knowledge about and attitudes toward life in Hindu society. Sandhyopaasan has been found as concise but compact form of yoga, mediation, healing, engaging, ands self controlling. Nontheless, it is expandable to specialization to each disciplin as well. This has been perpetuating beyond Hinduism. For instance, United Nations' Organization has declared 21 June as the International Day of Yoga from 2015. Means, Patanjali developed spiritual Yoga not only for Hindus now. Patanjali's philosophy of Ashtanga (eight fold path) Yoga has spirituality of meditation as well. Buddha's meditation, Zen's meditation, Mahesh Yogi's Transcendental meditation as well as all kind of yoga's root linked with Vedic Sandhyopaasan. Gaayatree Mantra is considered to be the most important Mantra (prayer chant). It is a tribute to the Sun God. Hindus recite Gaayatree Mantra each day. This combination of meta analysis, observation and reflection concludes that Sandhyopaasan has beyond meaning of mere yoga and meditation but scientific aspects as much as medical researches explored such engagements have inner treatment value specifically in psychotherapy and Alzheimer diseases. Going to the Sun thrice a day has scientific reason for health and hygiene. There are several benefits like enhancing eye power of the devotees, healthy life and stress free condition can be looked as "web of significance" as Geertz (1973) termed. The Sandhyopaasan performers have been benefiting from self energy, self healing health and tranquility. Finally, I love to cite Samanta et al. (2015) who quantitatively proved that similar practices to Sandhyopaasan, namely "yoga shakti" has found fruitful for Rheumatoid arthritis. This practice is drugless, easily adoptable, affordable, free from side effects and more natural alternative mode of treatments. This not only helpful to the patients but the humanity.

\section{References}

Acharya Kaundinnyanah, S. R. (2004). Brahma Yagya Paddhati (In Sanskrit) (Liturgical of Worship of Knowledge).Varanasi: Chaukhamba Vidyabhavan.

Acharya Kaundinnyayanah, S. R.(2066 Bikram Era). Sandhyopaasan Paddhati (Liturgical) (In Nepali and Sanskrit). Kathmandu: Ratna Pustak Bhandar. 
Acharya, S. R. (2013). Karmakanda Bhaskar (Ritual Insights) (Nepali Edition). Uttarakhanda: Shree Vedamatagayatree Trust.

Acharya, S. R. (2009). Vidyarambha Sanskar Vivechan (Education beginning: Ritual discourse). Uttarakhanda: Shree Veda matagayatree Trust.

Awasthi, L. D. (2004). Exploring Monolingual School practices in multilingual Nepal. PhD Thesis, Danish University of Education.

Büssing et al. (2012). Effects of yoga on mental and physical health: A short summary of reviews. Evidence-Based Complementary and Alternative Medicine. http://www.hindawi.com/ journals/ecam/2012/165410/ doi.org/10.1155/2012/165410

CDC (2005). Karmakandam (Rituals). Text book of Grade 9.

CDC (2007). Karmakandam (Rituals). Text book of Grade 6.

CDC (2014). Karmakaandam (textbook for grade 9). Kathmandu: Government of Nepal.

Chakravarthy, K. (2010). Yajurveda sandhyavandanam. Bangalore: Author.

Charlick, R. (2010). Mission possible: Introducing Jesus to the unreached. United Satates of America: Author.

Davis, M. D., and Hayes, J. A. (2011). What Are the Benefits of Mindfulness? A Practice Review of Psychotherapy-Related Research. Psychotherapy. 48, (2), $198-208$

Hussain, D. and Bhushan, B. (2010). Psychology of Meditation and Health: Present Status and Future Directions. International Journal of Psychology \& Psychological therapy. 10 (3), 439-451. http://www.ijpsy. com/volumen 10/num3/273/psychology-of-meditation-and-health-present-EN.pdf

Devi et al. (2011). Principle of Dincharya (Ideal life-style) in current scenario. International journal of ayurvedic \& herbal medicine 1(2) Sep-Oct 2011(39-45)

Douglas, M. (1966). Purity and danger: An analysis of the concept of the pollution and taboo. London: Routledge.

Geertz, C. (1973). The interpretation of cultures: Selected essays by Cliford Geertz.New York: Basic Book, Inc.

Hussain, D. and Bhushan, B. (2010). Psychology of meditation and health: Present status and future directions. International Journal of Psychology \& Psychological therapy. 10 (3), 439-451. http://www.ijpsy.com/volumen10/num3/273/ 


\section{psychology-of-meditation-and-health-present-EN.pdf}

Iyer, D. V. T. R. and Shastri, C. S. R. (1930). Sandhyavandanam with the bhashya of vedanti Sitarama Shastri. Madrads: The Sri Balamnorama Press.

Khalsa, D. S. (2014). The Work of the Alzheimer's Research and Prevention Foundation. Arizona: Alzheimer's Research and Prevention Foundation. http://www.alzheimersprevention. org/downloadables/Yoga and Medical Meditationtm.pdf

Mani, V. (1975). Puranic Encyclopedia. Delhi: Motilal Banarasi Das. Mishra, B. (2003). Vedic Education system (in Sanskrit and Hindi). Ujjain: Maharshi Sandipani Rashtriya Veda Vidya Pratishthan.

Pandya, P. (2010). Gayatri Sadhna (practice): Why and how? Mathura: Yug Nirman Yojana Vistar Trust.

Samanta et al. (2015) Intensive Research Study on Rheumatoid Arthritis through Yoga Shakti (A Drugless Therapy). Journal of Women's Health Care. (4) 6, doi:10.4172/2167$\underline{0420.1000263}$

Sannyasi Yogasindhu (1997). Yoga Magazine. http://www.yogamag. net/archives/1997/djuly97/yogpsyre.shtml

Shah, J. T. (2006). Therapeutic yoga. Mumbai: Vakils, Feffer and Simons Pvt. Ltd.

Shri Swami Shivananda (1999). All about hinduism. Utter Pradesh: The Divine Life Trust Society. http://www.dlshq.org/ download/hinduismbk.htm

Stubenrauch, J. M. (2011). Meditation As Good As Medication? American Journal of Nursing. March 2011 (111), 3,16. doi: 10.1097/10.1097/01.NAJ.0000395224.79799.32

Swami Chandresh (2010). The inner light. Kathmandu: Budhanilkantha Ashram.

Turner, V. (1979). Frame, flow and reflection: Ritual and drama as public liminality. Japanese Journal of Religious Studies 6 (4) December, 465-499.

Vedalankar, D. (Ed.) 2014. Sandhya-Agnihotra: A manual of Vedic prayer and Yajna. New Delhi: Vijaya Kumar Govind Ram Hasanand.

www.dlshq.org/download/hinduismbk.htm).

WWW.https://archive.org/details/yogasystemofpata00wooduoft

WWW.http://hinduonline.co/HinduReligion/AllAboutHinduism5. html

WWW.http://srivaishnavam.com/stotras/prata_sandhya.htm 